\title{
Modelling fine-scale distribution of the bottlenose dolphin Tursiops truncatus using physiographic features on Filicudi (southern Thyrrenian Sea, Italy)
}

\author{
Monica F. Blasi ${ }^{1, *}$, Luigi Boitani ${ }^{2}$ \\ ${ }^{1}$ Filicudi WildLife Conservation, Stimpagnato Filicudi, 98050 Lipari (ME), Italy \\ ${ }^{2}$ Department of Biology and Biotechnologies, University 'La Sapienza', Viale dell'Università 32, 00185 Rome, Italy
}

\begin{abstract}
Modelling cetacean distributions is crucial to understanding their ecology and to relating use patterns to environmental changes. In the present study, a combination of statistical methods was applied to model the distribution of bottlenose dolphin Tursiops truncatus with 18 physiographic variables around the Island of Filicudi, southern Italy. Principal components and clustering analyses were used to describe the habitat structure derived from mutually correlated predictor variables. Multivariate regression and canonical correlation analyses were used to find critical habitats and core use areas by combining the contribution of 2 response variables: the encounter rate and an index of use calculated according to the spatial behaviour of the dolphin groups. Three critical habitats were identified as distinct combinations of physiographic variables at a $1 \mathrm{~km}^{2}$ spatial scale. Two of these were associated with opportunistic and natural feeding activities. A third, a highly variable topographic habitat located in shallow waters at greater distance from the coastline, appears to serve as a resting/calving habitat by providing defence from anthropogenic pressures. The analysis also estimated an $80 \%$ shift from feeding to resting habitats associated with physiographic changes. Since the bottlenose dolphin encounter rate has decreased in recent years, the identification of core areas is useful in the preparation of local marine protected areas for the Aeolian archipelago. This analytical approach to studying dolphin-habitat relationships is relevant for conservation planning as it shows how environmental variability can modify dolphin distribution on a local scale according to the response variables relevant to the species.
\end{abstract}

KEY WORDS: Modelling distribution $\cdot$ Habitat use $\cdot$ Canonical correlation analysis $\cdot$ Aeolian Archipelago $\cdot$ Physiographic features $\cdot$ Bottlenose dolphin

\section{INTRODUCTION}

Modelling the distribution of marine vertebrates is useful for analysing how movement patterns change over time and space in relationship to changes in the environment (Bailey \& Thompson 2009). Many studies have shown that the distribution of cetacean populations can be closely linked to underwater topography such as water depth and seabed gradient (Watts \& Gaskin 1986, Ross et al. 1987, Selzer \& Payne 1988,
Frankel et al. 1995, Gowans \& Whitehead 1995, Baumgartner 1997, Raum-Suryan \& Harvey 1998, Karczmarski et al. 2000, Ferguson \& Barlow 2001, Ferguson et al. 2006), but the role of these determinants varies among regions and species, making it difficult to generalize the observed relationship. However, understanding the function of habitat features in determining distribution is a necessary step in planning management and conservation measures (Cañadas \& Hammond 2006). 
The bottlenose dolphin Tursiops truncatus is widely distributed in the Mediterranean, but localized populations are often threatened by anthropogenic activities. As habitat preferences may vary among populations, it is important to study the requirements of each population and their habitat selection incorporating both biotic and abiotic predictor variables. In the Mediterranean, the bottlenose dolphin inhabits a wide variety of habitats, including continental shelf waters (De Segura et al. 2008), lagoons and enclosed seas, the waters surrounding islands and archipelagos and also deep waters offshore (Irvine et al. 1981, Forcada et al. 2004, Klatsky et al. 2007, Bearzi et al. 2009). Physiographic variables, such as depth and distance from the coastline, may influence the bottlenose dolphin distribution directly or indirectly by acting upon other biotic factors such as prey availability, predator avoidance, or the facilitation of social interaction (Wells et al. 1980, Scott et al. 1990, Wells \& Scott 2002). The spatial behaviour of these dolphins can be related to feeding habitats (Barros \& Odell 1990, Shane 1990), in particular to those habitats where their prey, mainly demersal fish, are abundant (Mioković et al. 1999, Henderson 2004, Weiss 2006). In the Mediterranean, the bottlenose dolphin diet includes several commercial fish species (Blanco et al. 2001), and, as fish stocks are declining (Bearzi \& Fortuna 2006), dolphins are increasingly coming into conflict with fisheries, especially where gillnets, in particular trammel nets, are used for coastal fisheries (Dìaz Lopez 2006, Dìaz Lopez \& Shirai 2007, 2008).

The complex geomorphology of the volcanic islands of the Aeolian archipelago (Sicily, southern Italy) is likely to have a significant influence on the distribution and abundance of the bottlenose dolphin (Millot 1987) and its prey, but currently the distribution of this species in relation to habitat variables is unknown. For example, geomorphological data indicate that the location of subaerial and submarine vents is strongly controlled by local tectonic structures involving the Alicudi-Filicudi sector (Favallim et al. 2005). It may be expected that the environmental features related to these structures provide optimal feeding and resting grounds for the local dolphin population.

Different techniques have been applied to cetaceanhabitat modelling (Davis et al. 2002, Forcada et al 2004, Redfern et al. 2006). Most studies exploring the relationship of distribution patterns with environmental variables are based on statistical regression, in which the presence/absence or abundance of cetaceans is regressed with a set of predictor variables (Baumgartner 1997, Moses \& Finn 1997, Hooker et al.
1999, Hastie et al. 2005, Tynan et al. 2005, Bearzi et al. 2009). However, both linear regression and generalized linear models (GLMs) assume that the relationship between the response variable and the predictor variables is parametric, which may be an unrealistic assumption for many cetacean-habitat relationships (McCullagh \& Nelder 1989). Non-linear methods can be applied to analyse the relationship between each habitat variable and dolphin use patterns, but they work less effectively in recognising the pattern of correlation among a large number of mutually correlated environmental variables. Generalized additive models (GAM) have been applied to cetacean-habitat data collected during line-transect surveys (Hastie \& Tibshirani 1990, Cañadas et al. 2002, Panigada et al. 2008). Their major benefit lies in the flexibility in assessing non-linear cetacean-habitat relationships without imposing limitations on their form. However, GAMs are less efficient when the predictor variables interact with each other, especially when their number is large. In addition, the smoothed cetaceanhabitat relationships produced by GAMs can be difficult to interpret ecologically, as they may have complex functional forms strongly dependent on the response variables used in the model (Redfern et al. 2006). To address some of these limitations, cetaceanhabitat predictive models have been built by stratifying the response variable according to different animal features, such as the behavioural patterns or the presence of calves in the dolphin groups (Cañadas \& Hammond 2008).

In the present study, a combination of statistical techniques was applied to model the distribution of bottlenose dolphins with physiographic habitat variables on the Island of Filicudi (Aeolian Archipelago) (see Fig. 1). Principal components analysis (PCA) was used to reduce the dimension of the mutually correlated habitat variables and overcome the lack of independence among them. The component scores on the leading principal components (PCs) were used as habitat predictors and included in a regression model as they are independent by construction. Several studies have identified cetaceans' critical areas using density, use patterns, or behavioural variables (Ingram \& Rogan 2002, Hastie et al. 2004, Bearzi et al. 2008, De Segura et al. 2008). Encounter rate and group size were usually applied to estimate abundance in prediction models (Cañadas \& Hammond 2006). In our study, 2 response variables were applied in the regression model: the encounter rate and an entirely new index of use calculated on spatial characteristics of the dolphins' movement patterns. A multivariate regression analysis (MRA) was 
used to model dolphin distribution with the complexity of the habitat. Separate predictions were provided for each dependent variable, and a single best regression model was selected according to the significance of parameter estimations of 2 regression models considered contemporaneously (Sauvajot et al. 1998, MacNally 2000). Comparing the results of 2 predictions, an aggregative model was built (Ferguson et al. 2006). The aggregative response of the 2 response variables in the regression method accounted for small differences in the habitat structure likely related to different dolphin activities. On small spatial and temporal scales the distribution of a dolphin group can be associated with the different phases of the diurnal activity cycle. The behavioural activities of dolphins (feeding, travelling, socialising, etc.) were usually described by means of behavioural variables such as group organisation, swimming posture, types of dives and specific surface movements (Altmann 1974, Latherwood 1975, Shane 1990). Although behavioural variables were not used in the present study, an accurate description of habitat use can be provided by the spatial and temporal characteristics of dolphin movement patterns, such as the speed, direction and complexity of a dolphin group pathway collected during each sighting.

Since cetacean-habitat relationships may be strongly dependent on the response variables applied in the model, a clustering method was used to better stratify the role of each response variable to habitat selection. Three different critical habitats were identified as distinct combinations of physiographic variables. In addition, an estimate of the amount of shift from one critical habitat to another was obtained. This is a measure of the variation of habitat usage due to the daily dolphin movements. The likely relationship between these critical habitats and different behavioural activities of the dolphin groups could then be postulated. Finally, the core areas were calculated using canonical correlation analysis (CCA). To generate useful ecological interpretation of the core areas, the areas which maximise the 2 response variables for the best combination of habitat predictors on the leading canonical functions (CFs) were selected with 80 and $95 \%$ confidence interval (CI) bootstraps.

The application of this statistical approach to dolphin-habitat data is relevant for conservation planning as it allows us to better capture the habitat variance and spatial variability related to diurnal dolphin activities. This approach was applied to study dolphin-habitat relationships on a fine spatial/ temporal scale, i.e. dolphins' spatial distribution and time allocation at the $1 \mathrm{~km}^{2}$ scale and during the diurnal cycle. This scale was selected based on the patch size of coastal prey distribution, which, on a daily basis, may influence patterns of habitat use related to dolphin feeding activities (Hastie et al. 2004). Since the encounter rate of bottlenose dolphin groups has decreased over the last $7 \mathrm{yr}$, the identification of the dolphins' core areas, like coastal feeding areas, can be useful in the preparation of management plans for local marine protected areas in the Aeolian archipelago (Bailey \& Thompson 2009).

\section{MATERIALS AND METHODS}

\section{Data collection}

The study covered $280 \mathrm{~km}^{2}$ of the coastal area around the Island of Filicudi located at $38^{\circ} 35^{\prime} \mathrm{N}$, $14^{\circ} 34^{\prime} \mathrm{E}$ (Fig. 1). The island represents the upper part of a greater submarine volcanic structure rising from $1000 \mathrm{~m}$ in depth. The north-western shore is characterised by both high rock cliffs and shallow waters. In contrast, the south-eastern coast is characterised by greater depths, and in this area the sea bottom quickly drops to $1000 \mathrm{~m}$ depth.

The data used in the present study were collected in the summer (June to September) from 2005 to 2008. Additional sightings of Tursiops truncatus and effort data collected from 2009 to 2011 were used exclusively to calculate the yearly encounter rates (see response variables; subsection 'Data organisation'). Dolphins were sampled from a boat during daily surveys. A $5.6 \mathrm{~m}$ long $25 \mathrm{HP}$ outboard-powered research boat was used, travelling at an average speed of $11 \mathrm{~km} \mathrm{~h}^{-1}$ (standard deviation [SD] = $\pm 4 \mathrm{~km} \mathrm{~h}^{-1}$, range $=0$ to $26 \mathrm{~km} \mathrm{~h}^{-1}$ ). All surveys started and ended at the port of Pecorini (south-western shore; Fig. 1). Although routes varied depending on weather conditions, the best coverage of the study area was provided by alternately starting the surveys on the right/left side of the port (MacKenzie 2005) (Fig. 1) and following random routes into the study area. Two hundred surveys were performed over $322 \mathrm{~h}$ for a total of $3242 \mathrm{~km}$ surveyed. Each survey was conducted by at least 2 experienced observers at an eye elevation of ca. $3 \mathrm{~m}$. Observations were carried out under the following conditions: (1) daylight (divided into 1 to 5 intervals of $3 \mathrm{~h}$ each between 06:00 to $21: 00 h_{i}$ mean no. of hours $=2.3, \mathrm{SD}=1.4$; range $=1$ to 5 ) and good visibility ( $>300 \mathrm{~m}) ;(2)$ average Beaufort sea state of 0.91 (range $=0$ to 3 ) which did not differ between the early $(n=120$, mean $=0.9$, 


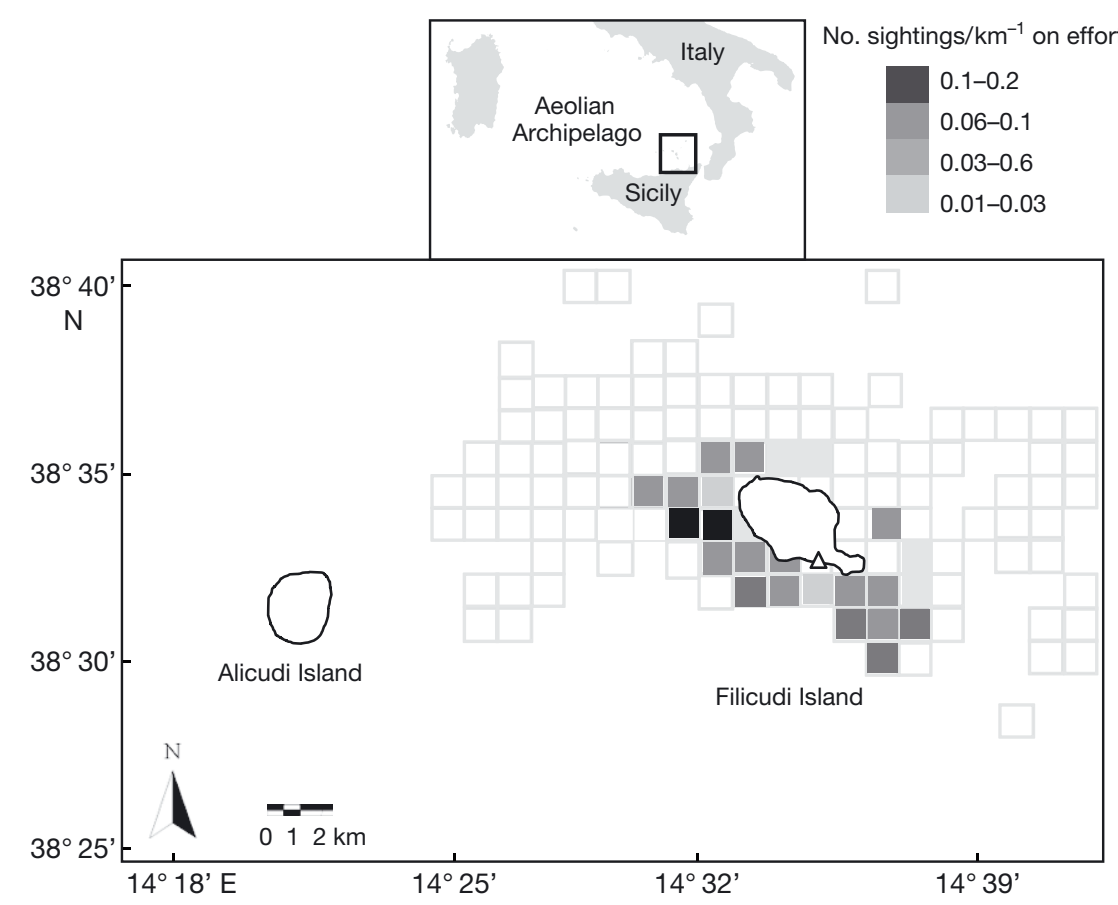

Fig. 1. Study area around the Island of Filicudi (Aeolian Archipelago, Sicily, Italy) showing the 121 cells of $1 \mathrm{~km}^{2}$ selected for the analysis. Grey scale shows different values of bottlenose dolphin Tursiops truncatus encounter rates (nos. of sightings per kilometre on effort) in each grid cell. $\Delta$ : port of Pecorini the same activity (Shane 1990). When a group split, one of the sub-groups was followed based on a random choice and independently of group size and/or activity (Mann 1999). A different focal group was defined if one or more individuals differed.

A behavioural catalogue adapted to the present study containing 7 behavioural modes (feed, travel, socialize, play, rest, court/sexual/mate, and mill) and 52 displays (states and events) was used to sample dolphin behaviour (Altmann 1974, Shane 1990). To distinguish between natural and disturbance behaviour, any apparent interaction between the focal group and anthropogenic factors (fishing gears or boats) was recorded. During each sighting the position of any fishing gear or boat was recorded if they were within $100 \mathrm{~m}$ of the focal group.

The following definitions (Altmann 1974) were used to record dolphin interactions with the research boat: (1) the individual is attracted to the boat, or alters course to swim directly $\mathrm{SD}=0.9)$ and late summer $(\mathrm{n}=80$, mean $=1.3, \mathrm{SD}=$ 1.1) $(\mathrm{p}=0.06)$, or between years (Kruskal-Wallis; $\mathrm{df}=$ $2, F=4.59, \mathrm{p}=0.012$ ).

Bottlenose dolphins were sampled using a combination of focal group observations with instantaneous data sampling (Altmann 1974) and photoidentification techniques (Würsig \& Würsig 1977, 1979, Würsig \& Jefferson 1990). Once sighted, the dolphin groups were approached in order to minimize disturbance and record their positions using a hand-held global positioning system (GPS, Garmin 12). The first position was recorded only when the boat reached $\leq 30 \mathrm{~m}$ distance from the focal group. Dolphin data were recorded at 3 min intervals (Shane 1990, Waples 1995) using the GPS, a tape recorder and digital video-cameras (GoPro Hero; Panasonic, Model SDR-S9). The purpose of these recordings was to identify the location of the focal group, its size and behavioural activity. At the same time, slide photographs were taken using a $35 \mathrm{~mm}$ autofocus camera (Nikon D70) with a 70 to $300 \mathrm{~mm}$ zoom lens to individually record the animals for photo-identification work.

A 'focal group' was defined as the number of animals observed in apparent association moving in the same direction and often, but not always, engaged in towards it to approach, but does not stay to bow-ride, (2) individual diving and surfacing in the wake of the boat, (3) swimming near the boats, (4) the individual diving and surfacing in the bow wave of the boat, (5) bow- or stern-wake riding, (6) the dolphin left the boat at the narrow port entrance, or (7) contact with boat and parts of it.

\section{Data organisation}

As the present study focused on identifying the natural use patterns of dolphins, the 3 min time intervals which included any interaction with anthropogenic factors (fishing nets or boats) or with the research boat were eliminated from the statistical analysis (10.3\% of the whole dataset). Photo-identification data were used to exclude any re-sightings of the same focal group on the same day, as this can over-estimate habitat use patterns (only 2 cases). mapped using ArcView GIS 3.2. The study area was divided into a grid of 280 cells of $1 \mathrm{~km}^{2}$. The $i$-th cell was used as the fundamental statistical unit. Sighting effort $\left(l_{i}\right)$ was measured for every grid cell by computing the length of the track line surveyed $(\mathrm{km}) \mathrm{calcu}-$
Group locations and patterns of movement were 
lated up to the starting point of each sighting. Since the speed of the research boat could be related to sea conditions, a comparison of sighting effort expressed in kilometres and in hours spent in the field was performed $(r=0.8, p<0.0001)$. Due to unequal survey effort across the grid, the analysis was restricted to the cells that were surveyed at least 3 times per year. In addition, the cells that fell outside the $95 \% \mathrm{CI}$ of the mean $l_{i}$ were also eliminated. This method (1) does not exclude the availability of habitats that are less frequently surveyed but accessed by the dolphins and (2) does not increase the availability of habitats that are less favourable to the animals (Porter \& Church 1987). A total of 121 grid cells was selected through this approach (Fig. 1).

\section{Physiographic variables}

The physiographic variables considered in the environmental model included the mean, range and standard deviation of depth and slope, characteristics related to the sea-bottom gradient and distance from the nearest coastline. Eighteen physiographic variables were extracted from 1:30000 scale nautical charts of the Hydrographic Institute of the Italian Navy (Table 1).

The physiographic variables were calculated for each grid cell using the MATLAB 7.6 statistical toolbox and 2 different approaches. First, an isobath model was constructed to compute variables in each grid cell using the isobath curves on the map and assuming a mean depth in the portion of sea between 2 isobaths. According to this model, the distance from one isobath to another was calculated as the minimum distance between them (in metres). The length of each isobath was approximated to a line and calculated as the sum of the lengths of the traced lines from the intersection of the isobath with the sides of the cell (in metres). The area $A_{\text {max-min }}$ represents the cell area encompassed within maximum and minimum isobaths.

Second, a model constructed from the depth values on the map (depth value model) was used to define physiographic variables that captured a detailed description of topography on a fine spatial scale $\left(1 \mathrm{~km}^{2}\right)$. The average number of depth values for each cell was $2.7( \pm 1.3 \mathrm{SD}$, range: $1-7)$, and as a result at least 1 depth value in each cell was represented. The distribution of the depth values on the map was a Poisson distribution, and a negative correlation was observed relative to the distance from the coast and number of isobaths per cell. The mean dis- tance from 2 generic depth values was $657 \mathrm{~m}( \pm 164 \mathrm{~m}$ $\mathrm{SD}$, range: 90-1212 $\mathrm{m}$ ). The significance of this model was good in the surveyed area as the cells with few reported depth values were also those with lower standard deviations of the sea-bottom gradient according to the distance from the coastline. According to this model the mean depth and its SD were calculated for each cell. A measure of the sea-bottom gradient (slope) was given as the ratio between the difference of the maximum and minimum depth values and the distance between them as:

$$
\text { Slope }_{i}=\left(\frac{\text { depth }_{\max i}-\operatorname{depth}_{\min i}}{\text { distance }_{\max i-\min i}}\right) \times \frac{A_{\max i-\min i}}{A_{\mathrm{t}}}
$$

where depth $\mathrm{max} i$ and $\operatorname{depth}_{\min i}$ are the maximum and minimum depths into the $i$-th cell, distance $\max i$-min $i_{i}$ is the distance between them, $A_{\max i-\min i}$ represents the cell area encompassed within maximum and minimum isobaths and $A_{\mathrm{t}}$ is the total area of the cell. Finally, the distance from the coast was computed as the mean length of the traced lines from the square vertexes and the centre of a cell to the nearest coast (in metres).

\section{Response variables}

Two response variables were calculated according to the group locations in each grid cell. The encounter rate is a measure of frequency of usage of an area according to the first location of the dolphin group for each sighting. Encounter rates were calculated for each $i$-th map cell using the formula $E_{i}=$ $n_{i} l_{i}^{-1}$, where $n_{i}$ and $l_{i}$ are, respectively, the number of sightings and the kilometres of sighting effort in the $i$-th cell. To check if encounter rates for these cells were effort biased, the correlations between encounter rate and kilometres surveyed (-0.001) and number of sightings (0.12) were tested. As expected, correlations were not significant $(\mathrm{p}=0.10$ and $\mathrm{p}=$ 0.30 , respectively). The yearly encounter rates were calculated as the number of sightings divided by the sighting effort in each year using the data collected during summer from 2005 to 2011.

Since a better measure of habitat use can be obtained from the movement patterns of the focal groups, some usage variables were calculated according to the group locations recorded for the entire duration of each sighting. Movement patterns were defined according to the shift of the focal groups from one cell to another in the grid. The following usage variables were determined for the $i$-th cell $c_{i}$ : (1) 'permanence time' $\left(p_{c i}\right)$, as the sum of the 


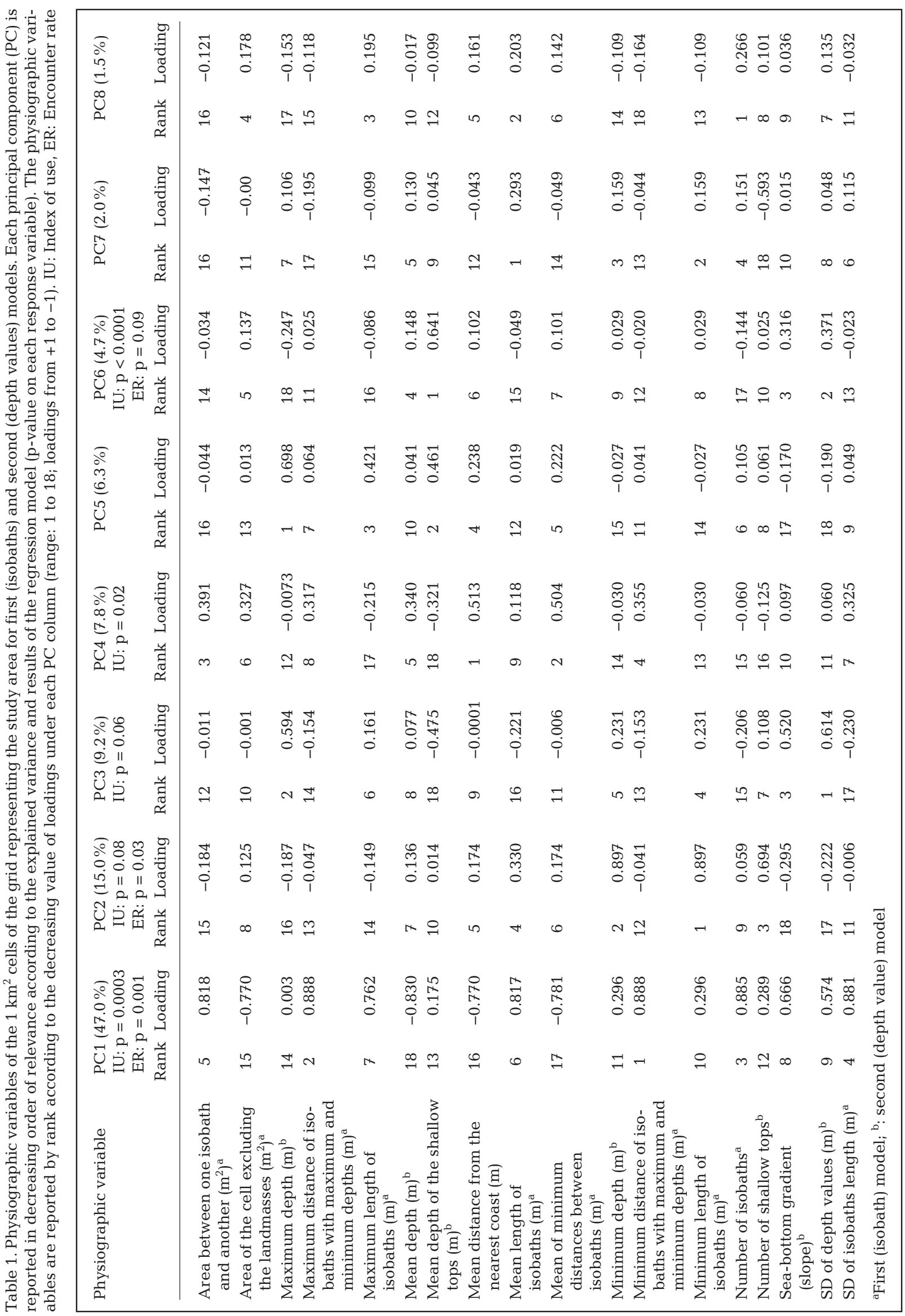


total time in minutes spent by the focal groups; (2) 'passage frequency' $\left(f_{c i}\right)$, as the sum of the total number of focal group passages, excluding the initial 3 min set of each sighting; (3) 'attractors' $\left(a_{C i}\right)$, as the number of times a focal group was observed to move toward a cell coming from 1 of the 8 cells closer to this, calculated for each sighting and then as a total sum; and (4) 'tortuosity' $\left(\tau_{c i}\right)$, as the sum of the intersections in the dolphin movement paths calculated for each sighting and then as a total sum. An index of use $\left(U_{i}\right)$ was calculated for the $i$-th cell according to the added values of the different usage variables. $U_{i}$ was calculated as:

$$
U_{i}=\left(\frac{p_{c_{i}}}{p_{\mathrm{T}}}+\frac{f_{c_{i}}}{f_{\mathrm{T}}}+\frac{a_{C_{i}}}{a_{\mathrm{T}}}+\frac{\tau_{c_{i}}}{\tau_{\mathrm{T}}}\right) \times \frac{l_{\mathrm{T}}}{l_{i}}
$$

where $l_{\mathrm{T}}$ is the total sighting effort calculated as the sum of the track lines $l_{i}$ expressed in kilometres computed in each cell and $p_{\mathrm{T}}, f_{\mathrm{T}}, a_{\mathrm{T}}$ and $\tau_{\mathrm{T}}$ are the total permanence time, passage frequency, attractors and tortuosity, respectively, calculated as the sum of the $p_{c i}, f_{c i r} a_{c i}$ and $\tau_{c i}$ computed in each cell. To avoid negatively biasing the permanence time in the cell where dolphins were observed at the end of each sighting, the sighting was terminated only when the animals left their last position (moved to another cell) and at the end of a 3 min interval. In addition, in order to reduce the correlation of $U_{i}$ and the encounter rate due to a low-duration sighting, all sightings with $<3$ three-minute intervals ( $24 \%$ of sightings) were excluded from the $U_{i}$ calculation. The mean duration of a sighting was $56.0 \mathrm{~min}( \pm 49.1 \mathrm{~min}$ $\mathrm{SD}$; range: $12-180 \mathrm{~min}$ 95\% CI = $2.8 \mathrm{~min}$; $4683 \mathrm{~min}$ total).

\section{Data analysis}

\section{Habitat description}

The spatial structure of the environment used by dolphins was investigated by means of a PCA using the SAS 8.1 software. PCA partitions the habitat variance among axes that are orthogonal and mutually independent (Jongman et al. 1995) as they are linear combinations of the physiographic predictors. The PCs were sorted by explained variance (Jolliffe 1972), with the signal components appearing first and the noisy part of the information relegated to the latter components. The component scores, the transformed variable values on the new ordination axes, represent a smaller set of new predictor variables, the habitat predictors, that include the correlation patterns of the original physiographic variables (Lebart et al. 1984, Jongman et al. 1995). The loadings, the Pearson correlation coefficients between PCs and variables, on the discriminating PCs were used to identify correlations between physiographic variables since these were related to the variance explained by such a component. The PCA was applied using the $1 \mathrm{~km}^{2}$ grid cells as statistical units. Only the leading PCs, describing at least $95 \%$ of the system variance, were used to identify groups of cells with similar physiographic features. The component scores were represented on a plot. Small correlation patterns between the physiographic variables were identified according to correlation plots on the minor PCs included in $95 \%$ of the system variance. The residual variance, representing the noisy part, was excluded from the analysis.

Since the number of physiographic variables is large and they interact with each other, a discrete classification of habitat features may help to ecologically interpret the PCA results. A $k$-means disjoint clustering (Spath 1985) was applied to the component scores of the leading PCs. This was used to stratify the study area according to different combinations of physiographic variables. The $\mathrm{R}^{2}$ values were used to assess the optimal number of 'habitat clusters' (H-clusters) by comparing the values obtained by running the procedure with different numbers of clusters. The $\mathrm{R}^{2}$ values were plotted against the number of clusters, and the procedure was stopped when the values of the curve plateau did not differ by increasing the numbers of clusters (95\% CI) (Milligan \& Cooper 1985, Gordon 1999). The selected Hclusters were sorted according to their latitude and longitude locations and plotted on the habitat map.

\section{Modelling distribution}

An MRA was applied to construct a dolphin-habitat prediction model and to examine the relationships between response and physiographic variables. The Proc REG statement in SAS was used (Sall 1981, Freund \& Littell 1986). The component scores of the leading PCs (95\% CI) were used as predictor variables in the model. These new predictors were independent contributions of physiographic variables to habitat structure. The 2 response variables, the encounter rate and the index of use were simultaneously used in the model. Separate predictions, parameter estimates (intercept and PCs) and their contribution to the distribution model were provided for each response variable as 
a result of the procedure. For each regression any predictors included in the model appeared in the analysis of variance statement. The $\mathrm{R}^{2}$ and adjusted $\mathrm{R}^{2}$ values were calculated, and the following coefficients were estimated: (1) root MSE was the standard deviation of the error term, and was the square root of the mean square error and (2) the coefficient of variation $(\mathrm{CV})$ that was a measure of variation of the data (root MSE/mean of the dependent variable multiplied by 100). A single best regression model was selected according to the results of the 2 single regressions considered contemporaneously. A list of the discriminating physiographic variables was obtained according to the loading values on the PCs significantly selected by both predictions (95\% CI bootstrap on each PC).

\section{Discrimination of critical habitat}

In order to investigate whether distinctive combinations of physiographic variables were associated with different dolphin use patterns, the contribution of each response variable to the selection of critical habitat was also analysed. A $k$-means clustering was applied to the 121 cells according to the values of encounter rate and index of use. These use clusters (U-clusters) stratified the grid cells on the basis of the combined values of both index use and encounter rate. Groups of cells with different combinations of the 2 response variables were identified. The encounter rate-index of use relationships were reported in a correlation plot for each U-cluster. A chisquared and a likelihood ratio chi-squared test were performed to compare the groups of cells according to H-cluster and U-cluster classifications. Significant $\mathrm{H}$-clusters, the critical habitat, were selected according to the mean values $( \pm \mathrm{SD})$ of each response variable on the H-clusters. Since the encounter rate is calculated using the locations of the focal groups at initial sighting times, while the index of use is computed using usage pattern variables for the dolphin groups, a shift from one critical habitat to another is expected while tracking the focal group locations during each sighting. The amount of shift from one critical habitat to another was calculated as the percentage increase/decrease of the mean values of each response variable on the significant $\mathrm{H}$-clusters. According to H-cluster classification, groups of cells were also represented in the plots of component scores of the leading PCs. The correlation patterns of the original physiographic variables associated with these $\mathrm{H}$-clusters were provided by the loadings on the discriminating PCs. The loading values provide a group of habitat variables that are differentially correlated for each $\mathrm{H}$-cluster.

\section{Core areas}

A CCA was applied to the PCs selected as significant by the regression model. In a CCA, the similarities between variables are expressed so that the correlation between predictor and response variables is maximised (Lebart et al. 1984, Rencher 1992). This method identifies canonical correlations as independent correlation contributions, indicating distinct mechanisms through which the linkage between sets takes place. To generate an ecological interpretation of the core areas, the cells which maximise the 2 response variables for the best combination of habitat predictors on the leading CFs were selected. The core areas were obtained through a selection of the largest absolute component scores on the leading CFs $\left(V_{1}\right.$ and $\left.W_{1}\right)$, with 80 and $95 \%$ CI bootstraps. According to this criterion, the core areas were those which maximized the correlation between the Uclusters and $\mathrm{H}$-clusters on the leading CFs. The list of most informative cells was generated according to the intersection of U-clusters and $\mathrm{H}$-clusters in the plot of the leading $\mathrm{CFs}_{1}, V_{1}$ and $W_{1}$, respectively. Since our study is focused on finding the physiographic characteristics which are related to smallscale dolphin distribution, all the cells with a $>80 \%$ CI bootstrap on $W_{1}$, which is the leading canonical function related to the physiographic variables, were also included in the graph.

\section{RESULTS}

\section{Encounter rate}

Dolphin encounter rate was represented for each grid cell in the study area (Fig. 1). Dolphin encounter rate from 2005 to 2011 (Fig. 2) was also reported. A decrease of encounter rates from 2007 to 2008 was observed (Student's $t$-test: $t=0.05$ ).

\section{Habitat characterisation}

Eight PCs were enough to correctly classify $96 \%$ of habitat variability. Definite groups of cells corresponding to those areas with similar physiographic characteristics were identified on the PC1-PC2 


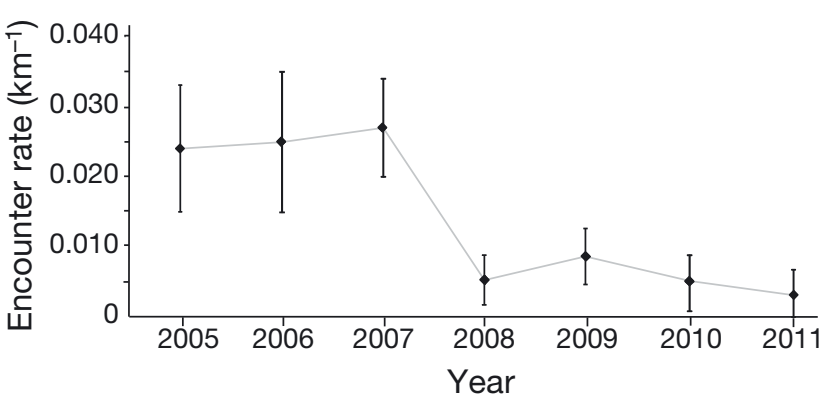

Fig. 2. Tursiops truncatus. Bottlenose dolphin encounter rates from 2005 to 2011. Encounter rates are calculated as the number of sightings divided by the survey effort $(\mathrm{km}$ surveyed) each year

(Fig. 3a), PC3-PC4 (Fig. 3b) and PC7-PC8 (Fig. 3c) component score plots. Some physiographic characteristics of these cells, the depth and its SD and the slope and distance from the coastline, were described on each plot according to the highest and lowest loadings on the corresponding PC. Each cell had different correlation patterns of the original physiographic variable on each PC. Nine H-clusters were also identified by applying $k$-means to the $\mathrm{PC} 1$ to $\mathrm{PC} 8$ component scores $\left(F=33.79, \mathrm{R}^{2}=0.49, \mathrm{CCC}=\right.$ 27). A representation of the $\mathrm{H}$-clusters sorted according to location on the study map and their statistical characteristics are shown in Fig. 4a. The 9 H-clusters were represented in each grid cell as a number, from 1 to 9 , according to their statistical characteristics (Fig. 4a).

\section{Modelling distribution}

Only depth and distance from the coastline were directly correlated to the encounter rate, while no other variable linearly correlates with the index of use (data not shown). Only the longitude was significant by application of MRA using the physiographic variables directly as predictors (model: $F=3.77, \mathrm{p}=$ $0.0016, R^{2}=0.13$; longitude: $p=0.0012$ ). This result suggests that a combination of predictors may be the reason for the observed dolphin distributions. The MRA was applied to the PC1 to PC8 component scores, as they represented a large portion of habitat variance. The dolphin-habitat model was better described by the index of use (model: $F=$ 5.82, $\mathrm{p}<0.0001, \mathrm{R}^{2}=0.29$, adjusted $\mathrm{R}^{2}=0.25$, root MSE $=9.31$, dependent mean $=4.20, \mathrm{CV}=221.73$ ) than by the encounter rate (model: $F=2.81, \mathrm{p}=$ $0.007, \mathrm{R}^{2}=0.20$, adjusted $\mathrm{R}^{2}=0.11$, root MSE $=$ 0.017 , dependent mean $=0.00692, \mathrm{CV}=237.97$ ). $\mathrm{PC} 1, \mathrm{PC} 2$ and $\mathrm{PC} 8$, in decreasing order of rele- vance, were significantly selected by the encounter rate $(\mathrm{PC} 1, \mathrm{p}=0.001 ; \mathrm{PC} 2, \mathrm{p}=0.03 ; \mathrm{PC} 8, \mathrm{p}=0.09$ ). PC7, PC1, PC4, PC3 and PC2, in decreasing order of relevance, were significantly selected by the index of use (PC7, p < 0.0001; PC1, p = 0.0003; PC4, p = $0.02 ; \mathrm{PC} 3, \mathrm{p}=0.06 ; \mathrm{PC} 2, \mathrm{p}=0.08$ ). A validation test was carried out to check whether the PC scores were able to separate cells with and without dolphin presence (PC1: encounter rate $\mathrm{p}<0.0001$, index of use $p<0.0001$; PC2: encounter rate $p=0.03$, index of use $p=0.09$ ). According to the highest and smallest loadings on PC1 (95\% CI) (Table 1), the best distribution model includes a reduced number of variables in decreasing order of relevance: maximum and minimum distances of isobaths with maximum and minimum depths, number of isobaths, standard deviation of the lengths of isobaths, area between one isobath and another and mean length of isobaths (Table 2). The physiographic variables calculated with the isobath approach were preferentially selected by the model.

\section{Discrimination of critical habitat}

Six U-clusters were obtained by application of $k$ means to the cells according to the values of response variables $\left(R^{2}=0.98\right)$. A significant relationship with the H-clusters was found (chi-squared test: $\mathrm{df}=40$, value $=65.1, p=0.007$; likelihood-ratio chi-squared: $\mathrm{df}=40$, value $=54.7, \mathrm{p}=0.060)$. A linear relationship between the 2 response variables on each U-cluster was observed (Fig. 5a). The Pearson correlation coefficients of the encounter rate with the index of use in each U-cluster were the following: U-cluster 1 $(-0.116)$, U-cluster $2(0.341), U$-cluster $3(0.538)$ and U-cluster 6 (-0.992). Correlation coefficients of Uclusters 4 and 5 were not reported in the correlation plot as only 1 cell was included in these clusters.

The encounter rate had the highest mean value on H-clusters 7 and 9, while the index of use had the highest mean value on H-clusters 7 and 1 (Fig. 5b). About $80 \%$ habitat shift from the $\mathrm{H}$-cluster 9 to $\mathrm{H}$ cluster 1 was estimated (Fig. 5b).

H-cluster 7 was characterised by a mean depth value of $317.3 \mathrm{~m}( \pm 105.1 \mathrm{~m} \mathrm{SD})$, bottom variability of $122.5 \mathrm{~m}( \pm 33.8 \mathrm{~m} \mathrm{SD})$, distance from the coastline of $2.5 \mathrm{~km}( \pm 1.5 \mathrm{~km} \mathrm{SD})$ and slope of $0.39 \mathrm{~m} \mathrm{~m}^{-1}$ $\left( \pm 0.07 \mathrm{~m} \mathrm{~m}^{-1}\right)$. H-cluster 9 was characterised by a low average distance from the coastline of $575.7 \mathrm{~m}$ $( \pm 355.1 \mathrm{~m} \mathrm{SD})$, mean depth of $106.4 \mathrm{~m}( \pm 87.7 \mathrm{~m} \mathrm{SD})$, high bottom variability of $75.9 \mathrm{~m}( \pm 47.3 \mathrm{~m} \mathrm{SD})$ and a slope of $0.24 \mathrm{~m} \mathrm{~m}^{-1}\left( \pm 0.16 \mathrm{~m} \mathrm{~m}^{-1}\right)$. The shallow 
a)

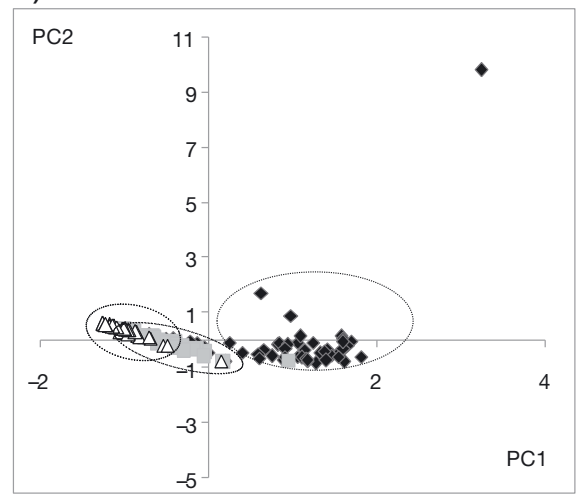

b)

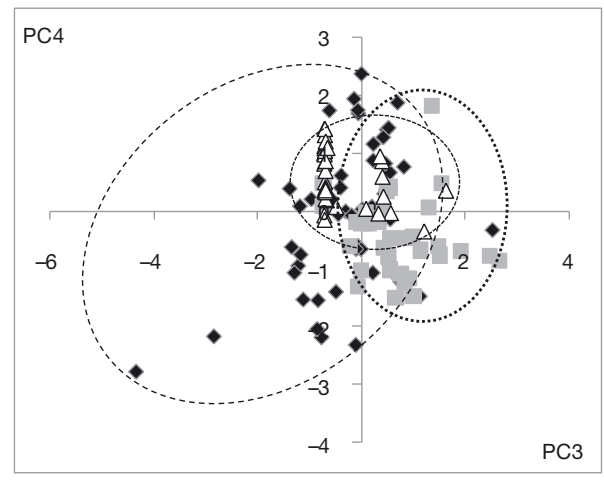

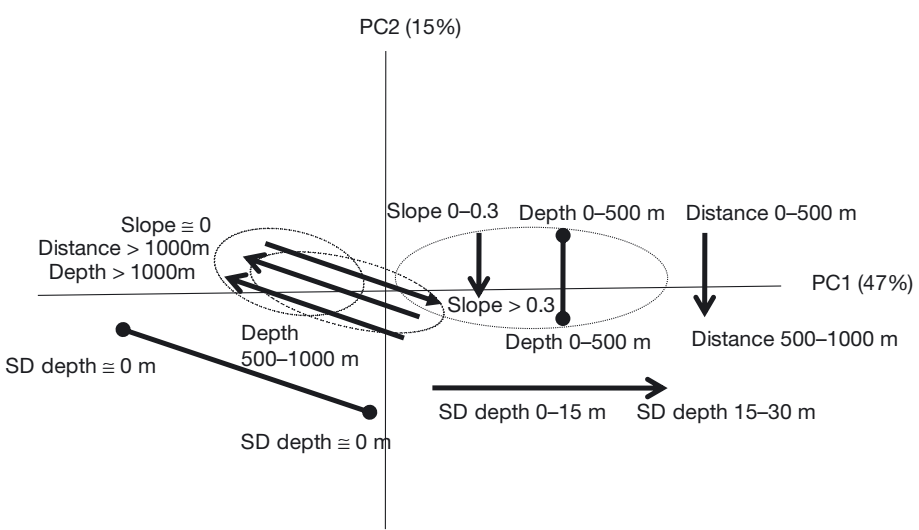

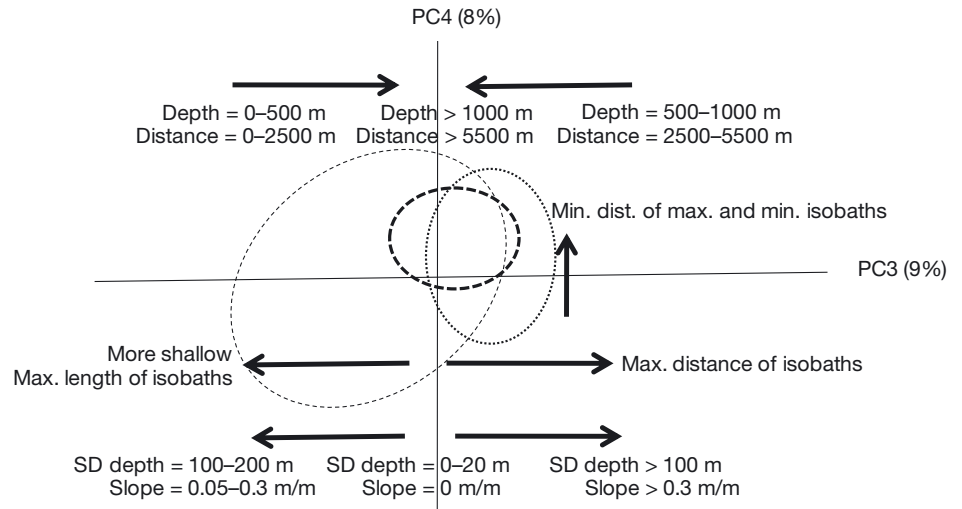

c)
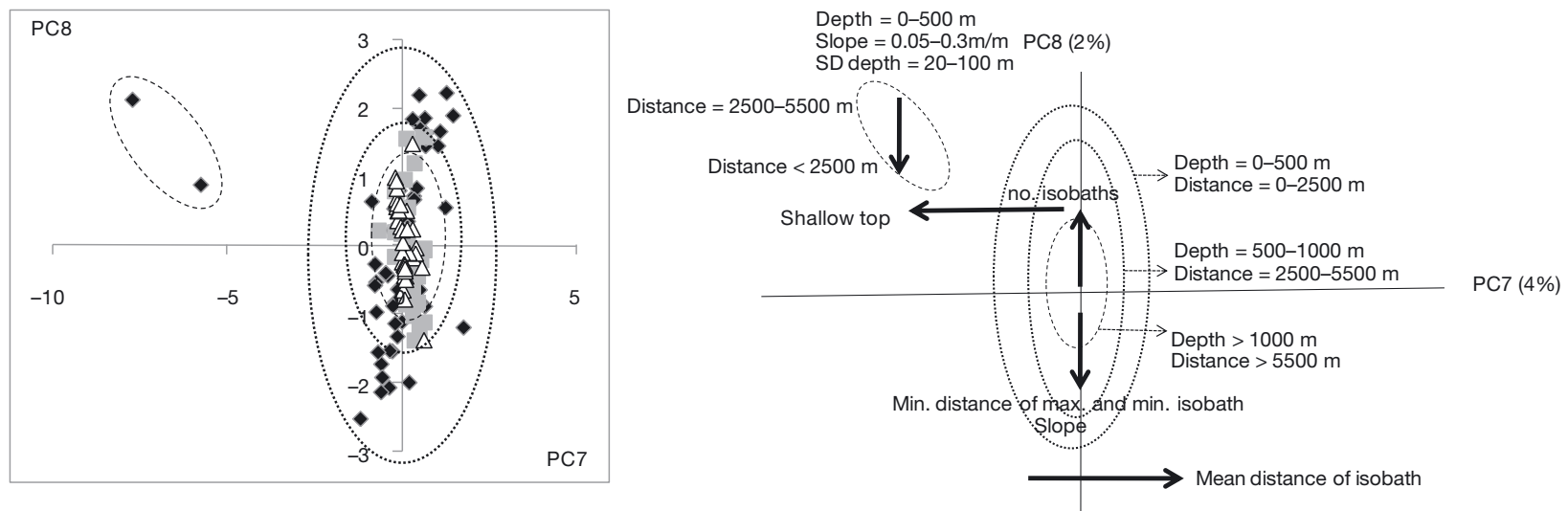

Fig. 3. Plot of the principal component (PC) scores for (a) PC1 with PC2, (b) PC3 with PC4 and (c) PC7 with PC8, according to the percentages of explained variance. The cells are located in 1 of the 4 squares in each plot according to the component score values. Left panels: different groups of cells, representing combinations of physiographic variables. Right panels: descriptions of the physiographic characteristics of the cells according to range values of depth and the standard deviations (SD) of depth, slope and distance from the coastline. : cells representing areas with depths of 500 to $1000 \mathrm{~m}, \mathrm{SD}$ of depth of $>100$ $\mathrm{m}$, slope of $>0.3 \mathrm{~m} \mathrm{~m}^{-1}$ and distance from the coastline of 2500 to $5500 \mathrm{~m}_{i} \diamond$ : cells representing areas with depths of 0 to $500 \mathrm{~m}$, $\mathrm{SD}$ of depth of 100 to $200 \mathrm{~m}$, slope of 0.05 to $0.3 \mathrm{~m} \mathrm{~m}^{-1}$ and distance from the coastline of $>5500 \mathrm{~m} ; \Delta$ : cells representing areas with depths of $>1000 \mathrm{~m}$, SD of depth of 0 to $20 \mathrm{~m}$, slope of $0 \mathrm{~m} \mathrm{~m}^{-1}$ and distance from the coastline of 0 to $2500 \mathrm{~m}$

waters of $\mathrm{H}$-cluster 1 were characterised by an average depth of $107 \mathrm{~m}( \pm 43.3 \mathrm{~m} \mathrm{SD}), \mathrm{SD}$ of depth of $52.9 \mathrm{~m}( \pm 32.2 \mathrm{~m} \mathrm{SD})$ and a slope of $0.16 \mathrm{~m} \mathrm{~m}^{-1}$ $\left( \pm 0.07 \mathrm{~m} \mathrm{~m}^{-1} \mathrm{SD}\right)$, and it included the top of a shallow $(48 \mathrm{~m})$ located at an average distance from the nearest north-western coast of $2.4 \mathrm{~km}( \pm 2.2 \mathrm{~km} \mathrm{SD})$. 


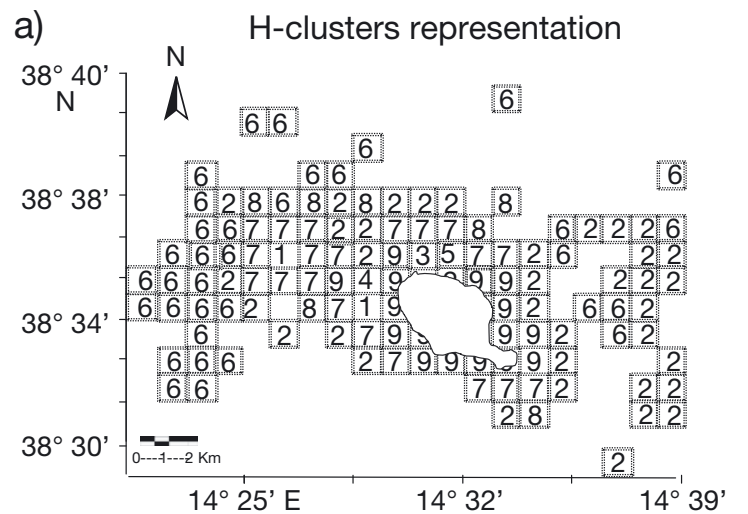

b)

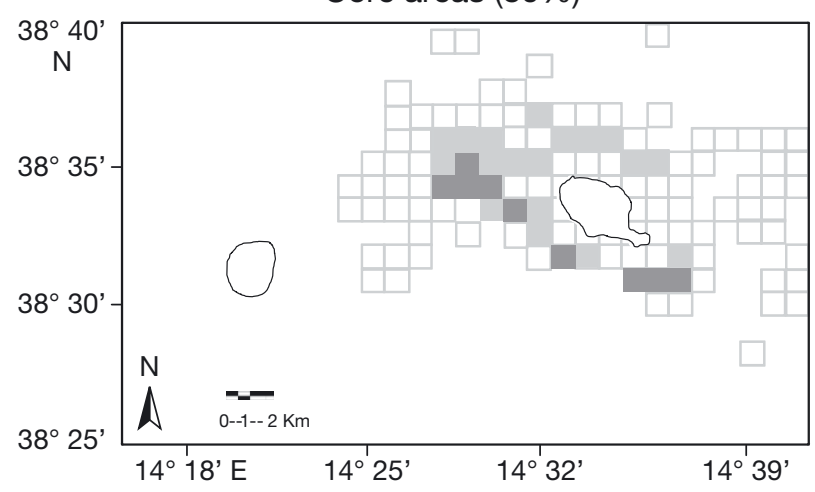

H-clusters characteristics

\begin{tabular}{|c|c|c|c|c|c|}
\hline H-cluster & Frequency & $\begin{array}{c}\text { RMS } \\
\text { SD }\end{array}$ & $\begin{array}{c}\text { Max. dist. from } \\
\text { seed to observation }\end{array}$ & $\begin{array}{c}\text { Nearest } \\
\text { clusters }\end{array}$ & $\begin{array}{c}\text { Distance } \\
\text { between } \\
\text { centroids }\end{array}$ \\
\hline 1 & 2 & 0.66 & 1 & 2 & 7.39 \\
\hline 2 & 39 & 0.54 & 3 & 6 & 1.96 \\
\hline 3 & 1 & - & 0 & 4 & 4.43 \\
\hline 4 & 1 & - & 0 & 3 & 4.43 \\
\hline 5 & 1 & - & 0 & 2 & 10.98 \\
\hline 6 & 34 & 0.63 & 2.32 & 2 & 1.96 \\
\hline 7 & 20 & 0.51 & 2.1 & 2 & 2.72 \\
\hline 8 & 7 & 0.55 & 2 & 2 & 2.93 \\
\hline 9 & 16 & 0.47 & 1.96 & 2 & 2.88 \\
\hline
\end{tabular}

Core areas $(95 \%)$

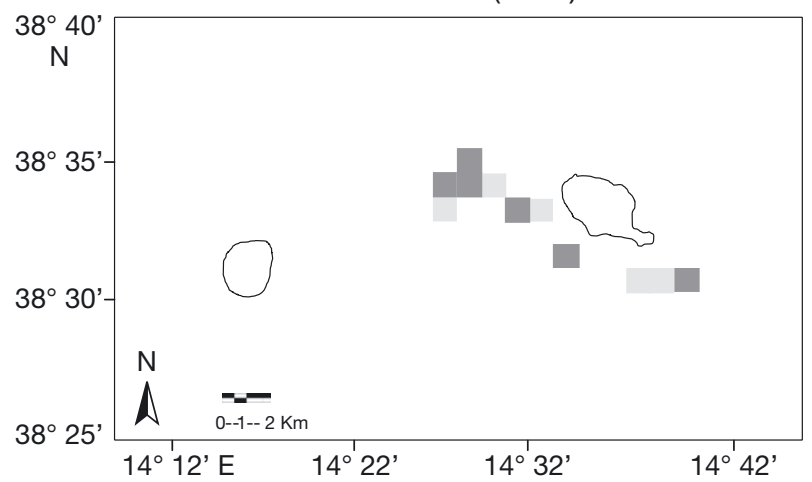

Fig. 4. (a) Habitat clusters (H-clusters) representation according to latitude and longitude of the cells in the study area (left panel). The $k$-means clustering results and statistical characteristics of the selected H-clusters (right panel): frequency, root mean squared (RMS) SD, maximum distance from seed to observation, nearest clusters and distance between centroids (Spath 1985). (b) Representation of core distribution areas. Left panel: $x$ - and $y$-axes show the 121 cells of the grid representing the study site (showing the islands of Alicudi and Filicudi; see Fig. 1). The 80 and $95 \%$ core areas are represented on the study site map with cells sorted according to latitude and longitude. Different grey shades and white cells are used to indicate the cell classification according to the values of the leading canonical functions, $V_{1}$ and $W_{1}$, respectively. Dark grey cells are those selected by intersection of the leading canonical functions in $>80 \% \mathrm{CI}$ and $>95 \% \mathrm{CI}$ of the $V_{1}$ and $W_{1}$ values. All the cells with $W_{1}>80 \% \mathrm{CI}$ are also included in the graph (light grey cells)

Distinct groups of cells, the H-clusters 7 to 9 and 1 , were identified on the plots of PC1-PC2 (Fig. 6a), PC3-PC4 (Fig. 6b) and PC7-PC8 (Fig. 6c) component scores. The physiographic variables on the minor PCs were associated with critical habitat differences. According to PC2 and PC7 loadings (Table 1), the best distribution model for $\mathrm{H}$-cluster 1 included the following terms: minimum length of isobaths, minimum depth, number of shallow tops, maximum distance of isobaths with maximum and minimum depths and area between one isobath and another (Table 2). The minor PCs, PC2 and PC8, accounted for more relevant differences of habitat characteristics of H-cluster 9 (Table 2). The slope, depth variability, maximum depth, number of isobaths, mean and maximum length of isobaths were selected by $\mathrm{H}-$ cluster 9 (Table 2).

\section{Core areas}

Two CFs were obtained through the application of the CCA, and only the first was significant in correctly classifying $85 \%$ of the response variables (test of $H_{0}: F=4.28$, df $=12$, denominator df $=226$, p < 0.000 ; canonical correlation $=0.54, \mathrm{SE}=0.06$ ). Pearson correlation coefficients between the response variables and their CFs $V_{1}$ and $V_{2}$, which allowed for the assignment of a shape to the scored correlations, were evidenced (encounter rate/ $V_{1}=0.61$, encounter rate $/ V_{2}=0.78$; index of use $/ V_{1}=-0.98$, index of use/ $V_{2}=-0.17$ ). The highest correlations between the PCs and the significant CFs for the habitat variables, $W_{1}$ and $W_{2}$, were attained for PC1 and PC7 $\left(\mathrm{PC} 1 / W_{1}=0.59, \mathrm{PC} 7 / W_{1}=-0.57\right)$. The correlation between PC1 and $V_{1}$ was 0.32 . Large absolute values 
Table 2. Physiographic differences of habitat clusters (H-clusters) are identified for each PC. The critical habitat classification (H-cluster 1, H-cluster 7 and H-cluster 9) is also reported for each discriminating PC (PC1, PC2, PC3, PC4, PC7 and PC8). Discriminating physiographic variables are reported for each $\mathrm{H}$-cluster according to the rank value of loadings on each significant PC (PC2, PC3, PC4, PC7 and PC8). The first 10 variables are reported according to the rank range (1 to 10) in decreasing order of relevance on PC1. For the minor PCs, the first 5 variables are reported according to the rank range (1 to 5$)$ and the last 5 variables according to the rank range (18 to 14), all in decreasing order of relevance. IU: Index of use, ER: Encounter rate

\begin{tabular}{|c|c|c|c|}
\hline Significant PC & H-cluster & Rank range & Discriminating physiographic variables \\
\hline $\begin{array}{l}\text { PC1 }(47.0 \%) \\
\text { IU: } p=0.0003 \\
\text { ER: } p=0.001\end{array}$ & H-cluster 1, 7-9 & $1-18$ & 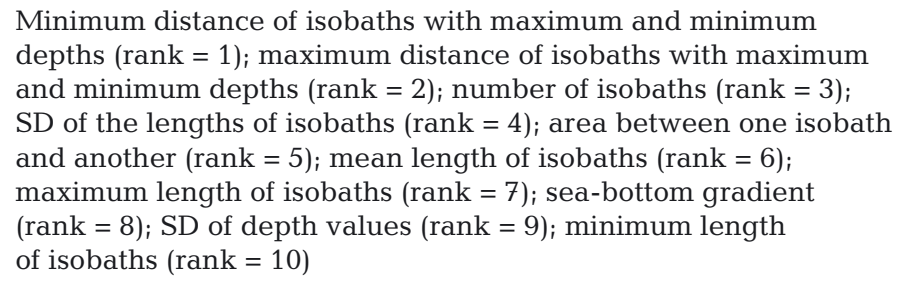 \\
\hline \multirow[t]{2}{*}{$\begin{array}{l}\text { PC2 }(15.0 \%) \\
\text { IU: } p=0.08 \\
\text { ER: } p=0.03\end{array}$} & H-cluster 1 & $1-10$ & $\begin{array}{l}\text { Minimum length of isobaths }(\mathrm{rank}=1) ; \text { minimum depth }(\mathrm{rank}=2) ; \\
\text { number of shallow tops }(\mathrm{rank}=3) ; \text { mean length of isobaths } \\
(\mathrm{rank}=4) ; \text { mean distance from the nearest coast }(\mathrm{rank}=5)\end{array}$ \\
\hline & H-cluster 7-9 & $18-11$ & $\begin{array}{l}\text { Sea-bottom gradient (slope) }(\mathrm{rank}=18) ; \mathrm{SD} \text { of depth values } \\
(\mathrm{rank}=17) ; \text { maximum depth }(\mathrm{rank}=16) ; \text { area between one isobath } \\
\text { and another (rank }=15) ; \text { maximum length of isobaths }(\mathrm{rank}=14)\end{array}$ \\
\hline \multirow[t]{2}{*}{$\begin{array}{l}\text { PC3 }(9.2 \%) \\
\text { IU: } p=0.06\end{array}$} & H-cluster 7 & $1-10$ & $\begin{array}{l}\text { SD of depth values }(\mathrm{rank}=1) ; \text { maximum depth }(\mathrm{rank}=2) ; \\
\text { sea-bottom gradient }(\text { slope })(\mathrm{rank}=3) ; \text { minimum length of isobaths } \\
(\mathrm{rank}=4) ; \text { minimum depth }(\mathrm{rank}=5)\end{array}$ \\
\hline & H-cluster 9 & $18-11$ & $\begin{array}{l}\text { Mean depth of the shallow tops }(\mathrm{rank}=18) ; \mathrm{SD} \text { of the lengths of } \\
\text { isobaths (rank }=17) ; \text { mean length of isobaths (rank }=16) ; \text { number } \\
\text { of isobaths (rank }=15) ; \text { maximum distance of isobaths with } \\
\text { maximum and minimum depths (rank }=14 \text { ) }\end{array}$ \\
\hline \multirow[t]{2}{*}{$\begin{array}{l}\text { PC4 }(7.8 \%) \\
\text { IU: } p=0.02\end{array}$} & H-cluster 7 & $1-11$ & $\begin{array}{l}\text { Mean distance from the nearest coast }(\mathrm{rank}=1) \text {; mean of minimum } \\
\text { distances between isobaths }(\mathrm{rank}=2) \text {; area between one isobath } \\
\text { and another }(\mathrm{rank}=3)_{\text {; }} \text { minimum distance of isobaths with } \\
\text { maximum and minimum depths }(\mathrm{rank}=4) \text {; mean depth }(\mathrm{rank}=5)\end{array}$ \\
\hline & H-cluster 1 & $18-12$ & $\begin{array}{l}\text { Mean depth of the shallow tops }(\mathrm{rank}=18) ; \text { maximum length of } \\
\text { isobaths }(\mathrm{rank}=17) \text {; number of shallow tops }(\mathrm{rank}=16) ; \text { number of } \\
\text { isobaths }(\mathrm{rank}=15) ; \text { minimum depth }(\mathrm{rank}=14)\end{array}$ \\
\hline \multirow[t]{2}{*}{$\begin{array}{l}\text { PC7 }(2.0 \%) \\
\text { IU: } p<0.0001\end{array}$} & H-cluster 9 & $1-10$ & $\begin{array}{l}\text { Mean length of isobaths }(\mathrm{rank}=1) ; \text { minimum length of isobaths } \\
(\mathrm{rank}=2) ; \text { minimum depth }(\mathrm{rank}=3) ; \text { number of isobaths } \\
(\mathrm{rank}=4) ; \text { mean depth }(\operatorname{rank}=5)\end{array}$ \\
\hline & H-cluster 1-7 & $18-11$ & $\begin{array}{l}\text { Number of shallow tops (rank }=18) ; \text { maximum distance of isobaths } \\
\text { with maximum and minimum depths (rank }=17) \text {; area between one } \\
\text { isobath and another (rank }=16) \text {; maximum length of isobaths } \\
(\text { rank }=15) ; \text { mean of minimum distances between isobaths } \\
(\text { rank }=14)\end{array}$ \\
\hline \multirow[t]{2}{*}{$\begin{array}{l}\text { PC8 }(1.5 \%) \\
\text { ER: } p=0.09\end{array}$} & H-cluster 1-9 & $1-9$ & $\begin{array}{l}\text { Number of isobaths }(\mathrm{rank}=1) ; \text { mean length of isobaths }(\mathrm{rank}=2) ; \\
\text { maximum length of isobaths }(\text { rank }=3) \text {; area of the cell excluding } \\
\text { the landmasses }(\mathrm{rank}=4) ; \text { mean distance from the nearest coast } \\
(\mathrm{rank}=5)\end{array}$ \\
\hline & H-cluster 7 & $18-10$ & $\begin{array}{l}\text { Minimum distance of isobaths with maximum and minimum depths } \\
\text { (rank =18); maximum depth (rank =17); area between one isobath } \\
\text { and another (rank }=16) \text {; maximum distance of isobaths with } \\
\text { maximum and minimum depths (rank = 15); minimum depth } \\
\text { (rank = 14) }\end{array}$ \\
\hline
\end{tabular}

of correlation indicate a dominant role exerted by the corresponding components in driving the correlations. The statistically significant correlations $(\mathrm{p}<$ 0.0001) were provided by Wixlamda, Pillai's trace, Otelling-Lawley and Royce max. root conservative tests (Rao 1973) for the MRA. Regarding the significance of a single regressor, the estimate is based on Rao's modified approximate F-statistic (Rao 1973).

The $80 \%$ core areas were selected in the plot of the $V_{1}$ versus $W_{1}$ CFs according to the intersection of 
a)

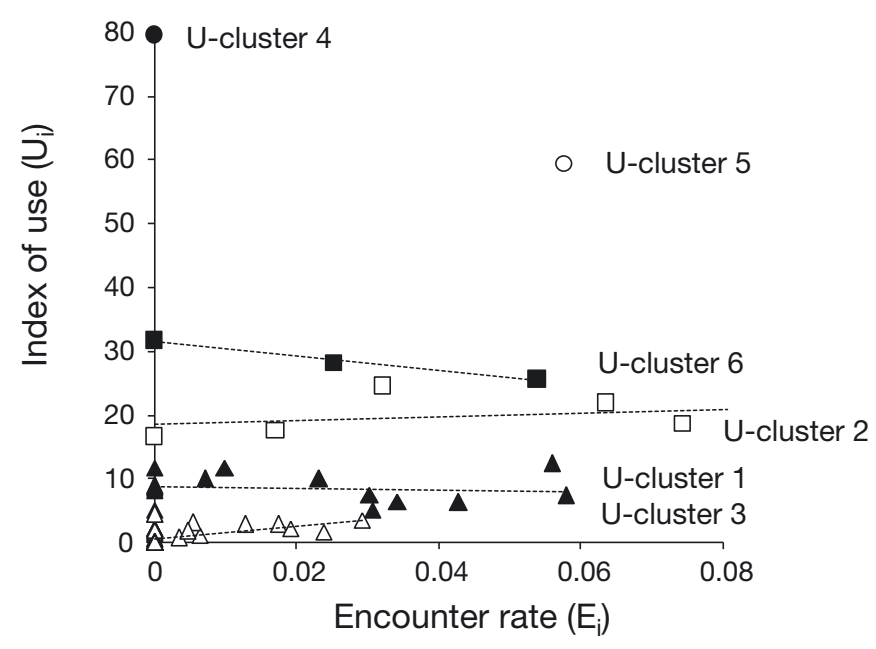

b)
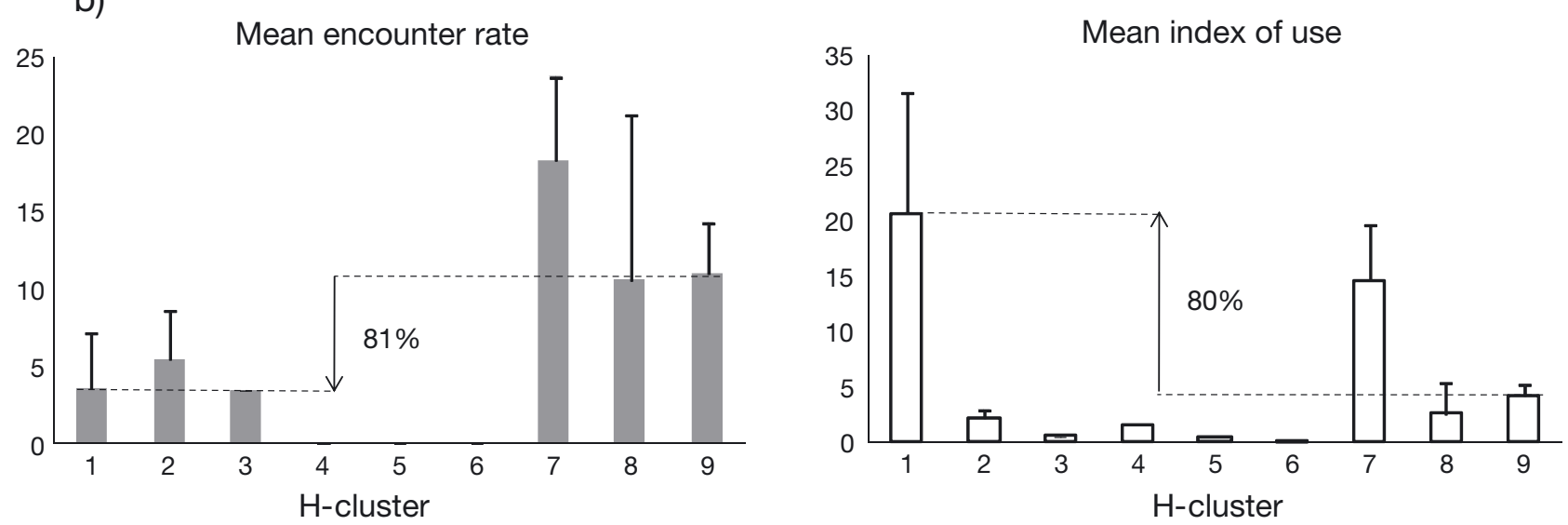

Fig. 5. (a) Correlation plot between the 2 response variables, encounter rate and index of use, for each use cluster (U-cluster). A linear relationship between the 2 response variables is shown in the plot. $\mathbf{\Delta}$ : U-cluster $1 ; \square$ : U-cluster $2 ; \Delta$ : U-cluster $3 ; \boldsymbol{\bullet}$ : Ucluster 4; O: U-cluster 5; $\mathbf{\square}$ : U-cluster 6. (b) Means (SD) of the encounter rate (left panel) and index-of-use values (right panel) for each H-cluster. The ca. $80 \%$ habitat shifts (increase/decrease) from H-cluster 9 to H-cluster 1 are reported

lines in $V_{1}=0.8$ and $W_{1}=0.9$ with the $80 \%$ CI bootstrap (Fig. 7). The $95 \%$ core areas were selected in the plot of the $V_{1}$ versus $W_{1}$ CFs based on the intersection of lines in $V_{1}=1.8$ and $W_{1}=1.9$ with the $95 \%$ CI bootstrap (Fig. 7). Based on this, the $95 \%$ core areas were also generated through the intersection of U-clusters 4 and 5 with H-clusters 1 and 7 (Fig. 7). The 80 and $95 \%$ core areas were represented on the study site map sorting the selected cells according to latitude and longitude (Fig. $4 \mathrm{~b}$ ). As $W_{1}$ was the leading canonical function related to habitat variables, all the cells with $W_{1}>80 \%$ CI and $W_{1}>95 \%$ CI were also included in the 2 graphs (Fig. $4 \mathrm{~b}$ ).

The $95 \%$ core areas were characterised by the physiographic features of critical habitats, H-clusters 1 and 7 . These characteristics were evidenced in Table 2.

\section{DISCUSSION}

The study of species-habitat relationships is of critical importance in order to identify the habitats and areas requiring conservation attention and particular management regimes, and habitat use patterns are an important component of studies of animal movement across heterogeneous environments (Lima 1998, Lima \& Dill 1990, Forney 2000, Morales \& Ellner 2002). Geographic distribution reflects the selection of specific habitat types that are visited according to their value in offering the resources needed by the dolphins (Johnston et al. 2005). Since different portions of the habitat are used for different activities during the annual, seasonal and diurnal cycles, shifts in the distribution of dolphins can be related to environmental diversity as well as dif- 
a)

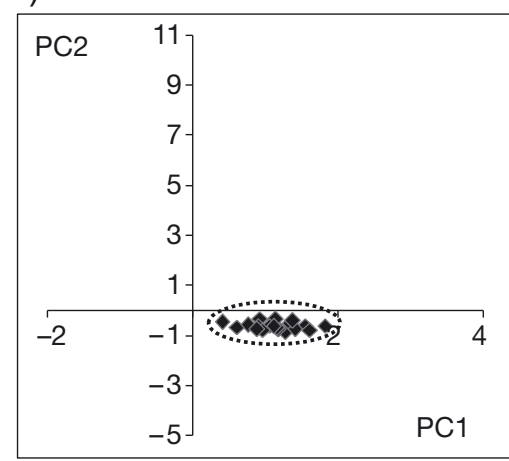

Cells with positive loading on PC1 and negative on PC2 s.c.

b)

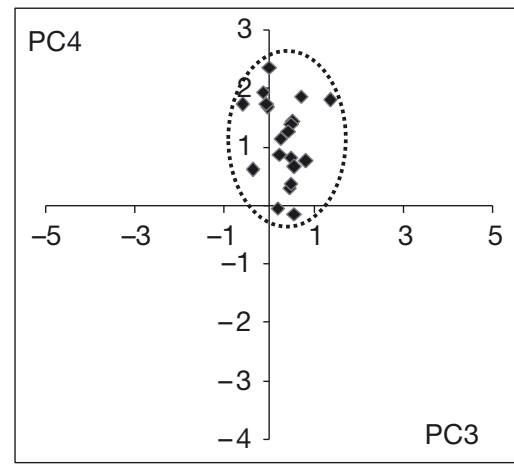

Cells with positive loading on PC4 s.c.

c)

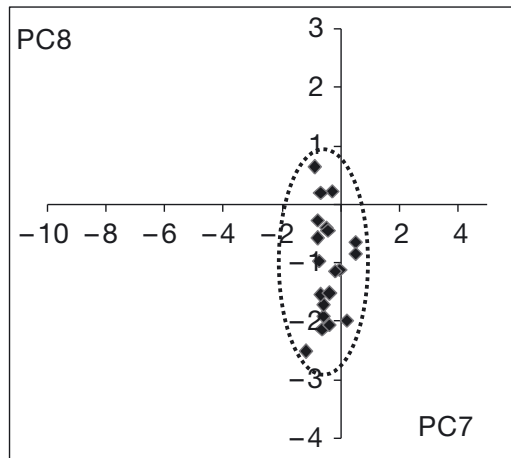

Cells with negative loading on PC2 and PC8 s.C.
H-Cluster 9

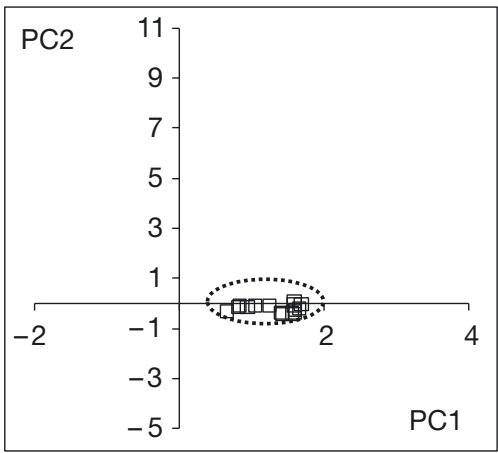

Cells with positive loading on PC1 and negative on PC2 s.c.

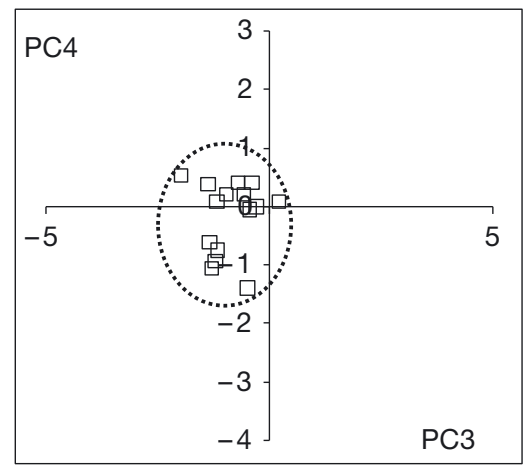

Cells with negative loading on PC3 s.c.

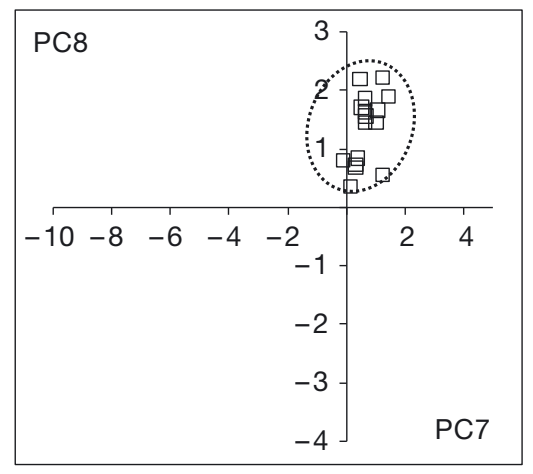

Cells with positive loading on $\mathrm{PC7}$ and PC8 s.c.
H-Cluster 1

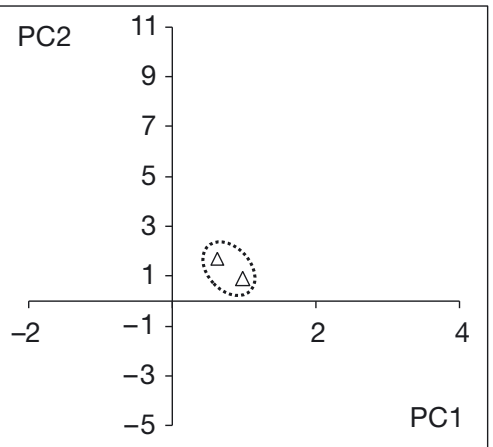

Cells with positive loading on PC1 and negative on PC2 s.c.
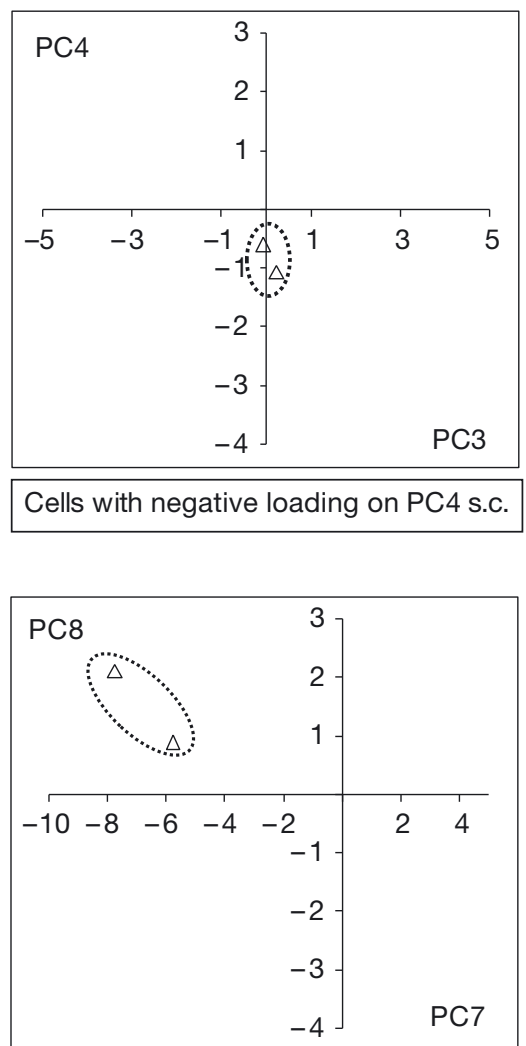

Cells with negative loading on PC7 and positive on PC8 s.c.

Fig. 6. H-cluster classification on the plots of principal component (PC) scores. Specific groups of cells are classified in H-cluster 7, H-cluster 9 and H-cluster 1 on each plot: (a) PC1-PC2, (b) PC3-PC4 and (c) PC7-PC8. The sign of the loadings on the discriminating PCs is also reported at the bottom of each plot (s.C.: component scores). Cells are classified as ( $)$ H-cluster 7 ; (口) H-cluster 9; $(\Delta)$ H-cluster 1

ferent combinations of habitat attributes (Wiens 1989, Levin 1992, Jaquet \& Whitehead 1996). In the present study, we focused on identifying the critical habitats and their usage patterns by bottlenose dol- phins in the areas surrounding the Island of Filicudi (Sicily, Italy), with the ultimate aim of contributing to the ongoing discussion on the establishment of a marine protected area. 

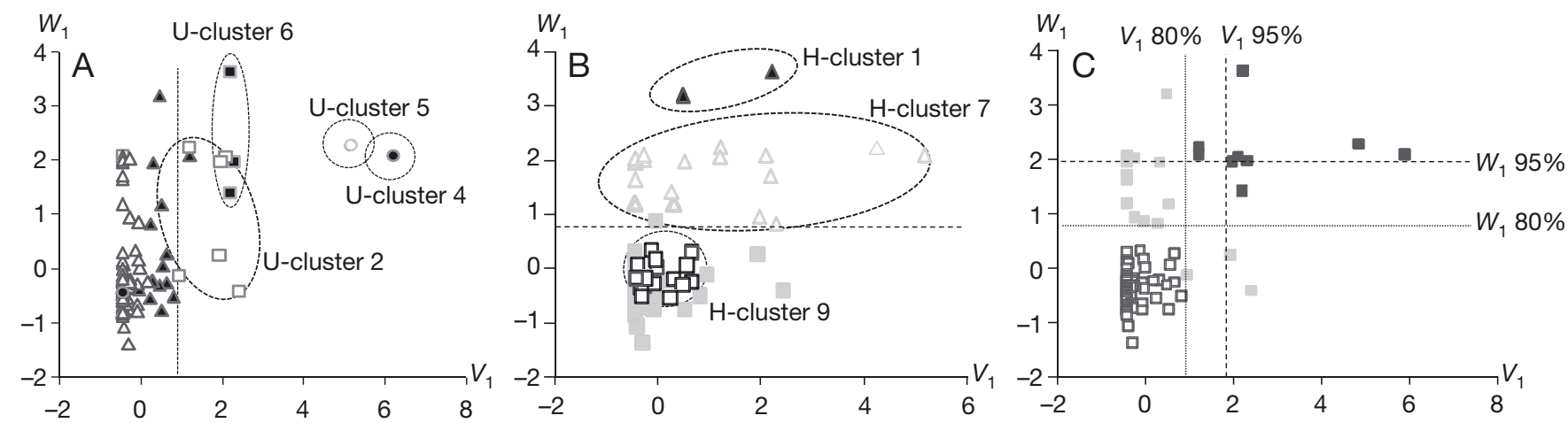

Fig. 7. Canonical correlation analysis plots showing the leading canonical functions, $V_{1}$ and $W_{1}$, outlining the contribution of combined response variables to habitat separation. (A) Cells representing the U-clusters selected by application of clustering to the 2 response variables are shown with different symbols: the cells representing the 6 U-clusters selected by application of

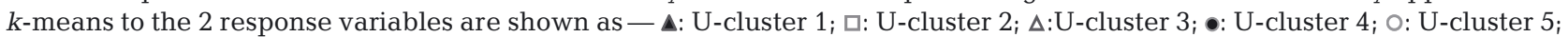
m: U-cluster 6. The significant U-clusters are also shown within the dashed lines. (B) Cells representing the $9 \mathrm{H}$-clusters selected by application of $k$-means to the PC1 to PC8 component scores are shown with different symbols. In particular, the 3 significant $\mathrm{H}$-clusters are shown as - $\mathbf{\Delta}$ : H-cluster $1 ; \Delta:$ H-cluster 7 ; $\mathbf{0}$ : H-cluster 9 ; they are also shown within the dashed lines. (C) Cells that characterise the 80 and $95 \%$ core areas are represented according to the intersections of $V_{1}$ and $W_{1}$ values with 80 and $95 \%$ CI. $\quad$ : cells obtained by intersection of $V_{1}=0.8$ and $W_{1}=0.9$ values according to $80 \%$ CI bootstrap (<80\% CI values); ㅁ: cells with $<80 \%$ CI values of $V_{1}$ and $W_{1}$; : other cells, in (B) \& (C)

\section{Getting the most from the predictors}

Usually, studies of cetacean habitats adopt physiographic (e.g. depth, slope) and oceaonographic (e.g. sea-surface temperature, salinity) predictors to represent conditions typical of good prey habitats, as well as oceanographic variables, such as thermocline depth and strength, which are expected to influence prey abundance and availability (Karczmarski et al. 2000, Ferguson et al. 2006). The habitat variables used in a regression model can be mutually dependent, affecting the results of the prediction and overestimating the contribution of correlated predictors. In the present study, PC and clustering analyses were used to describe the habitat structure derived from mutually correlated predictor variables. As regression assumes independence among the predictor variables, coupling this method with ordination techniques, such as PCA and clustering, can increase the ability to explore cetacean-habitat relationships when a large number of habitat variables are analysed simultaneously. In our study, PCA was used to combine a set of correlated physiographic variables into a reduced number of independent variables. The component scores on these new axes represent a smaller set of predictors, including the correlation patterns of the original habitat variables (Lebart et al. 1984, Jongman et al. 1995). A clustering was also applied to stratify the study area according to different combinations of physiographic variables. Groups of cells were classified in each critical habitat (H-cluster) according to the sign and value of component scores on the leading PCs. In addition, the correlation between physiographic variables in each critical habitat could be derived by analysing the PC loadings on the original variables (Rencher 1992).

Cetacean-habitat models should be created using the entire range of habitat variability, but the identification of habitat structures from cetacean presence/ use data is limited by the intrinsic difficulty in detecting low-variance signals (Borcard et al. 1992, Legendre et al. 2002). The PCA constructs linear combinations among the predictors, as the component scores embody the linear aspect of a complex relationship among 2 variables that could be highly non-linear. If a large number of variables describing a single habitat type, such as sea-bottom structure, are used together, they can be useful in examining the quantitative interrelated associations to determine the observed presence/use data. The inclusion of minor PCs in the regression model, such as those explaining lower percentages of habitat variance, may contain the problem of recognizing small patterns of correlations among physiographic variables. The minor components, the noisy part of habitat variance, are useful in identifying small physiographic differences between the selected critical habitats. For example, PC2 allowed us to describe several habitat differences between H-cluster 1 and $\mathrm{H}$-clusters 7 and 9.

\section{Using the appropriate response variables}

MRA and CCA were applied to find critical habitats and core use areas by combining the contribu- 
tion of 2 response variables: the encounter rate and an index of use calculated according to the spatial behaviour of the dolphin groups.

The contemporaneous application of the 2 dependent variables in the regression model proved to be extremely efficient in identifying the partition of habitat use across different critical habitats identified by distinct combinations of physiographic features. A difference in the result of the model was observed when the response variable was computed using dolphin group presence or usage data, as the encounter rates were calculated using the locations of dolphin groups at the starting points of the sightings, while the index of use was computed using movement pattern variables derived from the sightings. The index of use proved to be a better descriptor of dolphin habitat use. The index was computed according to use variables that are easily observed: permanence time and passage frequency are variables based on the intensity of use in an area, as they provide the time and frequency a particular site was occupied. The other path characteristics, such as tortuosity and attractors, are also expected to indicate the way an area is occupied and used. Although behavioural data were not included in this work, high tortuosity values were expected to indicate a detailed exploration of an area typical of foraging activity, while paths with a strong linear component were indicative of travelling to search for widely spaced resources (Zollner \& Lima 1999). As anthropogenic influences on dolphin distribution were eliminated from the analysis, the natural dolphin distribution was related to the behavioural cycle, such as feeding activities and searching for natural food resources. This index of use could be especially informative in situations where the animals switch to different use patterns when selecting a habitat on a fine spatial and temporal scale: for example, in the case of habitats that have high food availability, but are also the most dangerous (i.e. ecological traps). In these conditions, animals may have to trade-off food and safety according to the behavioural diurnal cycle (Hugie \& Dill 1994, Heithaus 2001, Heithaus \& Dill 2002).

\section{Temporal and spatial scales}

In order to understand how environmental variability reflects true changes in cetacean distribution, surveys should be specifically designed to optimise sampling at different temporal and spatial scales in all relevant habitats throughout a species' range (Redfern et al. 2006). Data on habitat use are often not simultaneous across temporal scales; for example seasonally recorded habitat data cannot predict daily or weekly distributions. In addition, the heterogeneity of prey patches is linked to oceanographic conditions (Jaquet \& Whitehead 1996), and, consequently, the cetaceanhabitat relationship defined by environmental features can be dependent on the spatial scale. The present study is, as far as we know, the first to use a particular combination of ordination techniques and regression methods to investigate dolphin-habitat relationships and model dolphin distribution at fine spatial $\left(1 \mathrm{~km}^{2}\right)$ and temporal scales (the time of a sighting). The temporal and spatial scales were selected as related to the home ranges of individual bottlenose dolphins, i.e. the spatial locations of dolphin groups recorded throughout diurnal sightings. The scales were selected in relation to the available bathymetric data which were expected to influence the patch size of the coastal prey distribution and therefore the behavioural cycle of the animals on a daily basis, such as their feeding ecology. The combination of the 2 approaches to calculate the physiographic variables for each cell of the grid was very advantageous to better define small habitat differences at this scale. For example, the habitat features of H-cluster 1 were related to the high variability of the sea-bottom structure in shallow waters at great distances from the coast, which is difficult to explain with an isobath model alone. A more appropriate description of the small differences associated with this critical habitat was provided by the combined contributions of the isobath and depth value approaches.

\section{Dolphins' critical habitats and core areas}

Three critical habitats as distinct combinations of physiographic variables were identified at a $1 \mathrm{~km}^{2}$ spatial scale. One of these was associated with opportunistic (H-cluster 9), and one, with natural (Hcluster 7) feeding activities. A third habitat (Hcluster 1), characterised by a high variability in the sea-bottom structure in shallow waters at great distances from the coastline, appears to serve as a resting/calving habitat by providing defence from anthropogenic pressures.

Dolphin use patterns were significantly related to shallower regions with the highest seabed gradients, according to earlier studies conducted in the Mediterranean Sea (Notabartolo di Sciara et al. 1993, Wilson et al. 1997, Cañadas et al. 2002, Ingram \& Rogan 2002, Azzellino et al. 2006, De Segura et al. 2008). Shallow waters are frequently sites of increased biological activity due to aggregations of 
prey species, which may be the primary driver of dolphin distribution patterns (Wilson et al. 1997, Blanco et al. 2001, Cribb et al. 2008). Although dolphin distribution is unlikely to be directly influenced by any of the physiographic variables considered in the present study, dolphins may tend to concentrate in areas where these features can indirectly affect the density of their prey (Davis et al. 2002). Water depth and certain features of bottom topography (e.g. underwater rocks) are known to correlate with the movement pattern dynamics influencing fish and dolphin distributions (Gelwick et al. 1997, Würsig \& Würsig 1979). Shallow waters provide a wide range of fish species that peak in abundance and diversity in spring and summer. Consequently, bottlenose dolphin distributions may change on a daily basis following the availability of this prey (Brager 1993, Fauchald 1999).

Around the Island of Filicudi, the bottlenose dolphin diet includes several commercial fish species, and, as fish stocks decline, dolphins are increasingly likely to come into conflict with the local artisanal fishery (authors' unpubl. data). Usually, during the spring and early summer months, when fishing activities occur throughout the area, habitat use of foraging dolphins also appears to be driven by the distribution of opportunistic food resources, such as trammel nets or fish farms (Reeves et al. 2001, Read 2005, Díaz Lopez \& Shirai 2008). Encounter rates were calculated using the locations of dolphin groups at the starting points of the sightings and the surveys were mainly conducted in the early morning when the fishery-dolphin interaction was more intense; thus, if this interaction were removed from the analysis, the selection of the H-cluster 9 could be related to habitat characteristics associated with trammel net distribution in the study area (authors' unpubl. data).

Although habitat use patterns are not directly related to the behaviour of dolphins, the use of shallow waters located at greater distances from the coastline (H-cluster 1) is expected to have an influence on the selection of resting and calving habitat, as a mechanism of defence under anthropogenic pressure (Wells et al. 1980, Mann 1999, Heithaus \& Dill 2002). Resting is probably the most dangerous activity that dolphins engage in because of reduced vigilance at this time and the lack of a refuge from risk factors (Heithaus 2001). Dolphins have to face increasing human disturbance in the form of habitat alteration, reductions in prey species populations and boating activity (Allen \& Read 2000). As the energetic cost of travel is low for dolphins and there is no benefit in staying in dangerous areas, they are expected to rest in the safest habitats (Heithaus 2001), especially during the summer seasons when fishermen increase their use of shallow habitats. It is also expected that, during the diurnal cycle, the dolphin groups occupy areas in order to minimise the travel costs from feeding grounds to the safest habitats. The estimated $80 \%$ shift from feeding to resting habitats (as indicated by associated physiographic variables) was associated with physiographic changes. As the mean duration of sightings was about $1 \mathrm{~h}$, this measure indicated a swift temporal trade-off between the 2 critical habitats. This measure is relevant for conservation planning as it shows how environmental variability can have a marked effect on dolphin distribution on a local scale according to the response variables relevant to the species as well as the use patterns typical of the local population.

The core areas identified in the present study confirmed their significance as key feeding and resting areas: they were found in other areas characterised by a high concentration of food resources as a result of the small-scale upwelling that maintained a stable flux of resource supplies (Harestad \& Bunnell 1979, Samuel et al. 1985, Benson et al. 2002). The dolphins showed a preference for cells with the precise combinations of physiographic variables in H-clusters 1 and 7, such as those with the highest values of shallow tops, minimum length of isobaths and minimum depths. In most models, depth was the selected variable over all other related habitat variables, indicating that the dolphins prefer a certain range of depths, not necessarily linked to distance from features such as the coast (Cañadas \& Hammond 2006). In the present study, the core areas were located in steep seabottom areas (especially around the 'Secca del Banco') and were associated with waters of between about 107 and $317 \mathrm{~m}$ depth, a bottom variability between about 53 and $123 \mathrm{~m}$ depth and a slope of between 0.16 and $0.39 \mathrm{~m} \mathrm{~m}^{-1}$.

Our data showed that the encounter rate of bottlenose dolphin off the Island of Filicudi has decreased in recent years and suggests that the species is declining across the study area. The results obtained in our study provide a key reference for assessing the core areas and critical habitats for bottlenose dolphins in the future implementation of marine protected areas in the Aeolian Archipelago and for designing management plans related to bottlenose dolphin conservation (Hooker et al. 1999). The highly variable topographic characteristics of the core areas identified in the present study will be useful in identifing similar habitat features off other islands in the Aeolian Archipelago in order to make an environmental suitability model for the bottlenose dolphin in this area and protect this species. 
Acknowledgements. Funding for this study was provided by Filicudi WildLife Conservation, and our volunteers were part of the Filicudi-Dolphin-Turtle-Project. Dr. Alessandro Giuliani provided valuable comments and suggestions. We are particularly grateful to editor Edward Gregr for his extensive work on an earlier draft and the excellent editorial advice that has enormously improved the manuscript.

\section{LITERATURE CITED}

Allen MC, Read AJ (2000) Habitat selection of foraging bottlenose dolphins in relation to boat density near Clearwater, Florida. Mar Mamm Sci 16:815-824

Altmann J (1974) Observational study of behaviour: sampling methods. Behaviour 49:227-267

Azzellino A, Gasparic S, Airoldi S, Nanid B (2006) Habitat use and preferences of cetaceans along the continental slope and the adjacent pelagic waters in the western Ligurian Sea. Deep-Sea Res I 55:296-323

Bailey H, Thompson PM (2009) Using marine mammal habitat modelling to identify priority conservation zones within a marine protected area. Mar Ecol Prog Ser 378: 279-287

Barros NB, Odell DK (1990) Food habits of bottlenose dolphins in the southeastern United States. In: Leatherwood S, Reeves RR (eds) The bottlenose dolphin. Academic Press, San Diego, CA, p 267-283

Baumgartner MF (1997) The distribution of Risso's dolphin (Grampus griseus) with respect to the physiography of the northern Gulf of Mexico. Mar Mamm Sci 13:614-638

Bearzi G, Fortuna CM (2006) Common bottlenose dolphin Tursiops truncatus (Mediterranean subpopulation). In: Reeves RR, Notarbartolo di Sciara G (compilers and eds) The status and distribution of cetaceans in the Black Sea and Mediterranean Sea. IUCN, Centre for Mediterranean Cooperation, Malaga, p 64-73

Bearzi G, Azzellino A, Politi E, Costa M, Bastianini M (2008) Influence of seasonal forcing on habitat use by bottlenose dolphins Tursiops truncatus in the northern Adriatic Sea. Ocean Sci J 43:175-182

> Bearzi G, Fortuna CM, Reeves RR (2009) Ecology and conservation of common bottlenose dolphins Tursiops truncatus in the Mediterranean Sea. Mammal Rev 39:92-123

Benson SR, Croll DA, Marinovic BB, Chavez FP, Harvey JT (2002) Changes in the cetacean assemblage of a coastal upwelling ecosystem during El Niño 1997-98 and La Niña 1999. Prog Oceanogr 54:279-291

Blanco C, Salomon O, Raga JA (2001) Diet of bottlenose dolphin (Tursiops truncatus) in the western Mediterranean Sea. J Mar Biol Assoc UK 81:1053-1058

> Borcard D, Legendre P, Drapeau L (1992) Partialling out the spatial component of the ecological variation. Ecology 73:1045-1055

Brager S (1993) Diurnal and seasonal behaviour patterns of bottlenose dolphins (Tursiops truncatus). Mar Mamm Sci 9:434-438

Cañadas A, Hammond PS (2006) Model-based abundance estimate of bottlenose dolphins off southern Spain: implications for conservation and management. J Cetacean Res Manag 8:13-27

> Cañadas A, Hammond PS (2008) Abundance and habitat preferences of the short-beaked common dolphin Delphinus delphis in the south-western Mediterranean: implications for conservation. Endang Species Res 4: 309-331
Cañadas A, Sagarminaga S, Garcìa-Tiscar S (2002) Cetacean distribution related with depth and slope in the Mediterranean waters off southern Spain. Deep-Sea Res I 49:2053-2073

Cribb N, Miller C, Seuront L (2008) Assessment of bottlenose dolphin (Tursiops aduncus) habitat characteristics in the estuarine waters of the Adelaide Dolphin Sanctuary, South Australia. J Mar Anim Ecol 1

> Davis RW, Ortega-Ortiz JG, Ribic CA, Evans WE and others (2002) Cetacean habitat in the northern oceanic Gulf of Mexico. Deep-Sea Res 49:121-143

De Segura AG, Hammond PS, Raga JA (2008) Influence of environmental factors on small cetacean distribution in the Spanish Mediterranean. J Mar Biol Assoc UK 88: 1185-1192

Díaz Lopez B (2006) Interaction between Mediterranean bottlenose dolphin (Tursiops truncatus) and gillnets off Sardinia, Italy. ICES J Mar Sci 63:946-951

> Díaz Lopez B, Shirai JAB (2007) Bottlenose dolphin (Tursiops truncatus) presence and incidental capture in a marine fish farm on the north-eastern coast of Sardinia (Italy). J Mar Biol Assoc UK 87:113-117

> Díaz Lopez B, Shirai JAB (2008) Marine aquaculture and bottlenose dolphin (Tursiops truncatus) social structure. Behav Ecol Sociobiol 62:887-894

Fauchald P (1999) Foraging in a hierarchical patch system. Am Nat 153:603-613

Favallim M, Karatson D, Mazzuoli R, Pareschi MT, Ventura G (2005) Volcanic geomorphology and tectonics of the Aeolian archipelago (southern Italy) based on integrated DEM data. Bull Volcanol 68:157-170

Ferguson MC, Barlow J (2001) Spatial distribution and density of cetaceans in the eastern tropical Pacific Ocean based on summer/fall research vessel surveys in 198696. Report No. LJ-01-04, Southwest Fisheries Science Center, La Jolla, CA

Ferguson MC, Barlow J, Fiedler P, Reilly SB, Gerrodette T (2006) Spatial models of delphinid (family Delphinidae) encounter rate and group size in the eastern tropical Pacific Ocean. Ecol Model 193:645-662

Forcada J, Gazo M, Aguilar A, Gonzalvo J, FernandezContreras M (2004) Bottlenose dolphin abundance in the NW Mediterranean: addressing heterogeneity in distribution. Mar Ecol Prog Ser 275:275-287

> Forney KA (2000) Environmental models of cetacean abundance: reducing uncertainty in population trends. Conserv Biol 14:1271-1286

> Frankel AS, Clark CW, Herman LM, Gabriels CM (1995) Spatial distribution, habitat utilization, and social interactions of humpback whales, Megaptera novaeangliae, off Hawaii determined using acoustic and visual means. Can J Zool 73:1134-1146

Freund RJ, Littell RC (1986) SAS system for regression, 1986 edn. SAS Institute, Cary, NC

Gelwick FP, Stock MS, Matthews WJ (1997) Effects of fish, water depth, and predation risk on patch dynamics in a north-temperate river ecosystem. Oikos 80:382-398

Gordon AD (1999) Classification. Chapman \& Hall/CRC, New York, NY

> Gowans S, Whitehead H (1995) Distribution and habitat partitioning by small odontocetes in the Gully, a submarine canyon on the Scotian shelf. Can J Zool 73: 1599-1608

Harestad AS, Bunnell FL (1979) Home range and body weight - a reevaluation. Ecology 60:389-402 
Hastie TJ, Tibshirani RJ (1990) Generalized additive models, Vol 43. Chapman \& Hall/CRC, Boca Raton, FL

> Hastie GD, Wilson B, Wilson LJ, Parsons KM, Thompson PM (2004) Functional mechanisms underlying cetacean distribution patterns: hotspots for bottlenose dolphins are linked to foraging. Mar Biol 144:397-403

> Hastie GD, Swift RJ, Slesser G, Thompson PM, Turrell WR (2005) Environmental models for predicting oceanic dolphin habitat in the Northeast Atlantic. ICES J Mar Sci 62: 760-770

Heithaus MR (2001) Predator-prey and competitive interactions between sharks (order Selachii) and dolphins (suborder Odontoceti): a review. J Zool (Lond) 253:53-68

Heithaus MR, Dill LM (2002) Food availability and tiger shark predation risk influence bottlenose dolphin habitat use. Ecology 83:480-491

Henderson EE (2004) Behavior, association patterns and habitat use of a small community of bottlenose dolphins in San Luis Pass, Texas. PhD thesis, Texas A\&M University, College Station, TX

> Hooker SK, Whitehead H, Gowans S (1999) Marine protected area design and the spatial and temporal distribution of cetaceans in a submarine canyon. Conserv Biol 13:592-602

Hugie DM, Dill LM (1994) Fish and game: a game theoretic approach to habitat selection by predators and prey. J Fish Biol 45(Suppl A):151-169

> Ingram SN, Rogan E (2002) Identifying critical areas and habitat preferences of bottlenose dolphins Tursiops truncatus. Mar Ecol Prog Ser 244:247-255

Irvine AB, Scott MD, Wells RS, Kaufmann JH (1981) Movements and activities of the Atlantic bottlenose dolphin, Tursiops truncatus, near Sarasota, Florida. Fish Bull 79: 671-688

> Jaquet N, Whitehead H (1996) Scale-dependent correlation of sperm whale distribution with environmental features and productivity in the South Pacific. Mar Ecol Prog Ser 135:1-9

Johnston DW, Westgate AJ, Read AJ (2005) Effects of finescale oceanographic features on the distribution and movements of harbour porpoises Phocoena phocoena in the Bay of Fundy. Mar Ecol Prog Ser 295:279-293

Jolliffe IT (1972) Discarding variables in a principal component analysis. II. Real data. Appl Stat 21:160-173

Jongman RHG, Ter Braak CJF, Van Tongeren OFM (1995) Data analysis in community and landscape ecology. Cambridge University Press, Cambridge

> Karczmarski L, Cockcroft VG, McLachlan A (2000) Habitat use and preferences of Indo-Pacific humpback dolphins Sousa chinensis in Algoa Bay, South Africa. Mar Mamm Sci 16:65-79

Klatsky LJ, Wells RS, Sweeney JC (2007) Offshore bottlenose dolphins (Tursiops truncatus): movement and dive behavior near the Bermuda pedestal. J Mamm 88 : 59-66

Latherwood S (1975) Some observations of feeding behavior of bottle-nosed dolphins (Tursiops truncatus) in the northern Gulf of Mexico and (Tursiops cf. T. gilli) off southern California, Baja California, and Nayarit, Mexico. Mar Fish Rev 37:10-16

Lebart L, Morineau A, Warwick K (1984) Multivariate descriptive statistical analysis. John Wiley, New York, NY

> Legendre P, Dale MRT, Fortin MJ, Gurevitch J, Hohn M, Myers D (2002) The consequences of spatial structure for the design and analysis of ecological field surveys. Ecography 25:601-615

Levin SA (1992) The problem of pattern and scale in ecology. Ecology 73:1943-1967

- Lima SL (1998) Stress and decision making under the risk of predation: recent developments from behavioral, reproductive, and ecological perspectives. Adv Stud Behav 27: 215-290

> Lima SL, Dill LM (1990) Behavioral decisions made under the risk of predation: a review and prospectus. Can J Zool 68:619-640

> MacKenzie DI (2005) What are the issues with presenceabsence data for wildlife managers? J Wildl Manag 69: 849-860

> MacNally R (2000) Regression and model-building in conservation biology, biogeography and ecology: the distinction between and reconciliation of 'predictive' and 'explanatory' models. Biodivers Conserv 9:655-671

Mann J (1999) Behavioral sampling methods for cetaceans: a review and critique. Mar Mamm Sci 15:102-122

McCullagh P, Nelder JA (1989) Generalized linear models, Vol 37. Chapman \& Hall, New York, NY

Milligan GW, Cooper MC (1985) An examination of procedures for determining the number of clusters. Psychometrika 50:159-179

Millot C (1987) Circulation in the West Mediterranean Sea. Oceanol Acta 10:143-149

Mioković D, Kovačić D, Pribanić S (1999) Stomach contents analysis of one bottlenose dolphin (Tursiops truncatus) from the Adriatic Sea. Natura Croat 8:61-65

Morales JM, Ellner SP (2002) Scaling up animal movements in heterogeneous landscapes: the importance of behavior. Ecology 83:2240-2247

- Moses E, Finn JT (1997) Using geographic information systems to predict North Atlantic right whale (Eubalanea glacialis) habitat. J Northwest Atl Fish Sci 22:37-46

Notarbartolo di Sciara G, Venturino MC, Zanardelli M, Bearzi G, Borsani JF, Cavalloni B (1993) Cetaceans in the central Mediterranean Sea: distribution and sighting frequencies. Ital J Zool 60:131-138

Panigada S, Zanardelli M, Mackenzie M, Donovan C, Melin F, Hammond PS (2008) Modelling habitat preferences for fin whales and striped dolphins in the Pelagos Sanctuary (western Mediterranean Sea) with physiographic and remote sensing variables. Remote Sens Environ 112: 3400-3412

> Porter WF, Church KE (1987) Effects of environmental pattern on habitat preference analysis. J Wildl Manag 51: 681-685

Rao CR (1973) Linear statistical inference and its applications, 2nd edn. John Wiley \& Sons, New York, NY

Raum-Suryan KL, Harvey JT (1998) Distribution and abundance of and habitat use by harbor porpoise, Phocoena phocoena, off the northern San Juan Islands, Washington. Fish Bull 96:802-822

Read AJ (2005) Bycatch and depredation. In: Reynolds III JE, Perrin WF, Reeves RR, Montgomery S, Ragen TJ (eds) Marine mammal research: conservation beyond crisis. The Johns Hopkins University Press, Baltimore, MD

> Redfern JV, Ferguson MC, Becker EA, Hyrenbach KD and others (2006) Techniques for cetacean-habitat modeling. Mar Ecol Prog Ser 310:271-295

Reeves RR, Read AJ, Notarbartolo di Sciara G (2001) Report of the workshop on interactions between dolphins and fisheries in the Mediterranean: evaluation of mitigation 
alternatives. ICRAM Workshop, Rome, May 2001. Document SC/53/SM3 presented at the 53rd Meeting of the International Whaling Commission, London

Rencher AC (1992) Interpretation of canonical discriminant functions, canonical variates and principal components. Am Stat 46:217-225

Ross GJB, Cockcroft VG, Butterworth DS (1987) Offshore distribution of bottlenose dolphins in natal waters and Algoa Bay, eastern Cape. S Afr J Zool 22:50-56

Sall JP (1981) SAS regression applications, revised edn. SAS Technical Report A-102, SAS Institute, Cary, NC

Samuel MD, Pierce DJ, Garton EO (1985) Identifying areas of concentrated use within the home range. J Anim Ecol 54:711-719

Sauvajot RM, Buechner M, Kamradt DA, Schonewald CM (1998) Patterns of human disturbance and response by small mammals and birds in chaparral near urban development. Urban Ecosyst 2:279-297

Scott MD, Wells RS, Irvine AB (1990) A long-term study of bottlenose dolphins on the west coast of Florida. In: Leatherwood S, Reeves RR (eds) The bottlenose dolphin. Academic Press, San Diego, CA, p 235-244

Selzer LA, Payne PM (1988) The distribution of white-sided (Lagenoryhnchus acutus) and common dolphins (Delphinus delphis) vs. environmental features of the continental shelf of the northeastern United States. Mar Mamm Sci 4:141-153

Shane SH (1990) Behavior and ecology of the bottlenose dolphin at Sanibel Island, Florida. In: Leatherwood S, Reeves RR (eds) The bottlenose dolphin. Academic Press, San Diego, CA, p 267-283

Spath H (1985) Cluster dissection and analysis. Ellis Horwood, Chichester

Tynan CT, Ainley DG, Barth JA, Cowles TJ, Pierce SD, Spear LB (2005) Cetacean distributions relative to ocean processes in the northern California Current System. Deep-Sea Res II 52:145-167

Editorial responsibility: Edward Gregr, Vancouver, British Columbia, Canada
Waples DM (1995) Activity budgets of free-ranging bottlenose dolphins (Tursiops truncatus) in Sarasota Bay, Florida. Master's thesis, University of California, Santa Cruz, CA

Watts P, Gaskin DE (1985) Habitat index analysis of the harbor porpoise (Phocoena phocoena) in the southern coastal Bay of Fundy, Canada. J Mammal 66:733-744

Weiss J (2006) Foraging habitats and associated preferential foraging specializations of bottlenose dolphin (Tursiops truncatus) mother-calf pairs. Aquat Mamm 32:10-19

Wells RS, Scott MD (2002) Bottlenose dolphins. In: Perrin WF, Würsig B, Thewissen JGM (eds) Encyclopedia of marine mammals. Academic Press, San Diego, CA

Wells RS, Irvine AB, Scott MD (1980) The social ecology of inshore odontocetes. In: Herman LM (ed) Cetacean behavior: mechanisms and functions. John Wiley \& Sons, New York, NY, p 263-318

- Wiens JA (1989) Spatial scaling in ecology. Funct Ecol 3: 385-397

- Wilson B, Thompson PM, Hammond PS (1997) Habitat use by bottlenose dolphins: seasonal and stratified movement patterns in the Moray Firth, Scotland. J Appl Ecol $34: 1365-1374$

Würsig B, Jefferson TA (1990) Methods of photo-identification for small cetaceans. In: Hammond PS, Mizroch SA, Donovan GP (eds) Individual recognition of cetaceans: use of photo-identification and other techniques to estimate population parameters. Rep Int Whal Comm Special Issue 12, 43-52

> Würsig B, Würsig M (1977) The photographic determination of group size, composition and stability of coastal purpoises (Tursiops truncatus). Science 198:755-756

Würsig B, Würsig M (1979) Behaviour and ecology of the bottlenose dolphin, Tursiops truncatus, in the South Atlantic. Fish Bull 77:399-412

Zollner PA, Lima SL (1999) Search strategies for landscapelevel inter-patch movements. Ecology 80:1019-1030

Submitted: November 11, 1010; Accepted: January 27, 2012 Proofs received from author(s): June 1, 2012 